\title{
Staphylococcus aureus colonization: modulation of host immune response and impact on human vaccine design
}

\section{Aisling F. Brown ${ }^{1+}$, John M. Leech ${ }^{1+}{ }^{1}$,Thomas R. Rogers ${ }^{2}$ and Rachel M. McLoughlin ${ }^{1 *}$}

${ }^{1}$ Host-Pathogen Interactions Group, School of Biochemistry and Immunology, Trinity Biomedical Sciences Institute, Dublin, Ireland

${ }^{2}$ Sir Patrick Dun Laboratory, Department of Clinical Microbiology, Trinity College Dublin, St James's Hospital, Dublin, Ireland

\section{Edited by:}

Fabio Bagnoli, Novartis Vaccines, Italy

\section{Reviewed by:}

Manuel Amieva, Stanford University

School of Medicine, USA

Clarissa Pozzi, Novartis V\&D, Italy

*Correspondence:

Rachel M. McLoughlin,

Host-Pathogen Interactions Group,

School of Biochemistry and

Immunology, Trinity Biomedical

Sciences Institute, Trinity College

Dublin, 152-160 Pearse Street, Dublin

2, Ireland

e-mail: rachel.mcloughlin@tcd.ie

${ }^{\dagger}$ Aisling F. Brown and John M. Leech have contributed equally to this work.
In apparent contrast to its invasive potential Staphylococcus aureus colonizes the anterior nares of $20-80 \%$ of the human population. The relationship between host and microbe appears particularly individualized and colonization status seems somehow predetermined. After decolonization, persistent carriers often become re-colonized with their prior $S$. aureus strain, whereas non-carriers resist experimental colonization. Efforts to identify factors facilitating colonization have thus far largely focused on the microorganism rather than on the human host. The host responds to $S$. aureus nasal colonization via local expression of anti-microbial peptides, lipids, and cytokines. Interplay with the co-existing microbiota also influences colonization and immune regulation. Transient or persistent $S$. aureus colonization induces specific systemic immune responses. Humoral responses are the most studied of these and little is known of cellular responses induced by colonization. Intriguingly, colonized patients who develop bacteremia may have a lower $S$. aureus-attributable mortality than their non-colonized counterparts. This could imply a staphylococcal-specific immune "priming" or immunomodulation occurring as a consequence of colonization and impacting on the outcome of infection. This has yet to be fully explored. An effective vaccine remains elusive. Anti-S. aureus vaccine strategies may need to drive both humoral and cellular immune responses to confer efficient protection. Understanding the influence of colonization on adaptive response is essential to intelligent vaccine design, and may determine the efficacy of vaccine-mediated immunity. Clinical trials should consider colonization status and the resulting impact of this on individual patient responses. We urgently need an increased appreciation of colonization and its modulation of host immunity.

Keywords: Staphylococcus aureus, colonization, host response, immunomodulation, $\mathrm{T}$ cells, microbiota, vaccine

\section{INTRODUCTION}

Staphylococcus aureus can be a human commensal or a potentially lethal opportunistic pathogen. It is one of the leading causes of a variety of community-acquired and hospital-acquired bacterial infections. S. aureus is one of the most common causes of bacteremia, and carries a higher mortality than any other - 65$70 \%$ in the pre-antibiotic era, and currently $20-40 \%$ mortality at 30 days despite appropriate treatment $(1,2)$. It is also an important cause of other deep-seated infections including osteomyelitis, septic arthritis, endocarditis, device-related infections, and pneumonia. S. aureus is unusual for its propensity to cause primary bacteremia and serious infections among young, otherwise healthy people, as well as in those with risk factors (3). While invasive disease is by far the most acute and severe, the greatest burden of morbidity is due to skin and soft tissue infections (SSTIs), which are extremely common, often chronic, and frequently recurrent.

Invasive disease continues to occur despite improved adherence to infection prevention practices, and the organism has steadily evolved resistance to every licensed anti-staphylococcal agent to date. In this context, clinical need has driven research efforts toward strategies to develop an anti-S. aureus vaccine. Our lack of knowledge of what elements of the immune system are important in recovery from or prevention of human infection is staggering. This ignorance of what may constitute a protective immune response in humans makes designing vaccines even more challenging. Less than 10 candidates for passive or active immunization have progressed to clinical studies to date, and none have shown efficacy in preventing disease.

Intriguingly, despite its impressive armory and invasive opportunism, S. aureus replicates and evolves in a large proportion of the human population as a harmless colonizing organism and never causes disease. This review will explore interactions between colonizing $S$. aureus and the human immune system and describe the compelling impact colonization has on the risk and outcome of invasive S. aureus infection. Finally, we will consider the particular challenges of designing a vaccine against a colonizing organism and the importance of examining the potential priming effect of colonization in future clinical trials.

\section{UNDERSTANDING HUMAN STAPHYLOCOCCUS AUREUS COLONIZATION \\ SITES AND PATTERNS OF S. AUREUS COLONIZATION}

Humans are frequently exposed to $S$. aureus and it colonizes most of us, either for long or short periods at various stages throughout our lives. The primary $S$. aureus reservoir in humans is the anterior nares. Extra-nasal colonization sites include skin, throat, 
perineum, vagina, and gastrointestinal tract (4-6). Exclusively sampling nasal sites to determine whether a person is colonized at a single point in time will miss $50 \%$ of those colonized elsewhere (7). Nonetheless it appears that the nasal site is often the source of inoculation of other sites via hand transfer, and the greater the bacterial load in the nares, the higher the likelihood that other body sites are colonized and that the colonization is persistent $(8-10)$. We will largely focus on the role of nasal carriage in this review as that is what has been most extensively investigated.

Nasal carriers may fall into two categories - persistent carriers and non-persistent carriers (11). Approximately 20\% of individuals are persistently colonized with a relatively high bacterial load, and the remainder are either never colonized or only intermittently with low numbers of bacteria (12). Much of the existing literature examining the role of colonization is weakened by sampling participants at a single time point only, precluding differentiation between persistent and intermittent carriers. There is no standard definition of how many cultures should be taken and what fraction should be positive before determining carrier status, despite various proposals (9). This is unfortunate as it seems that the differences between persistent and non-persistent carriage patterns are critical in determining the risk of subsequent infection and may thus influence the nature of response to potential candidate vaccines (11).

\section{TRANSMISSION, DYNAMICS, AND NATURAL HISTORY OF COLONIZATION}

A small minority $(<5 \%)$ of neonates are colonized by $S$. aureus at birth, mainly if born by normal delivery in a vaginally colonized mother (6). In the first 2 weeks of life, colonization with mainly maternal strains rapidly occurs in half of infants, but this falls to adult rates by 6 months of age, coincident with the development of acquired immunity (13). One quarter of neonates are not colonized by $S$. aureus at all in the first 2 years of life, and what determines this resistance to acquisition is unknown.

Transmission of $S$. aureus occurs almost exclusively as a result of direct skin-to-skin contact, or contact with recently contaminated fomites $(14,15)$. Nonetheless, even proven contact with the organism does not necessarily result in subsequent colonization, and certain hosts remain non-carriers. In one study, only a minority of patients with prior culture-proven $S$. aureus skin infection remained colonized with the organism in the convalescent phase, and only $25 \%$ of their household contacts were colonized with the index infecting strain (7). Colonization rates among pre- and postclinical medical students are not altered by increased exposure of the post-clinical group to S. aureus in healthcare settings (16). This suggests important host differences may confer resistance to colonization.

The relationship between each host and their colonizing strain is extremely personalized. The duration of colonization among nasal carriers has been measured from 70 days to 8 years. It seems longer among persistent carriers, although methods used to prove the isolate remains the same were suboptimal in comparison to contemporary techniques $(11,17-20)$. More recently, wholegenome sequencing has allowed deeper exploration of carried strains. It seems that nasal colonization results from a single founding organism that multiplies over time with the evolution of limited minor genetic variations (21). Persistent carriers may sequentially acquire a new strain that replaces their original colonizing organism (22). Experimental inoculation of established persistent and non-carriers with multiple strains resulted in most volunteers returning to their original "natural" carrier state, and sometimes even reverting to their original colonizing strain $(11,23)$.

\section{RISK FACTORS FOR COLONIZATION}

The prevalence of $S$. aureus in the anterior nares of a sample of healthy Europeans at a single time point was $21.6 \%$, with slightly higher rates in men and younger adults (24). Accurate assessments of persistent carriage are more difficult to determine, but among relatively healthy adults chronic skin disease, recent skin infection, male sex, and being a non-smoker are associated with increased nasal colonization rates $(25,26)$.

Certain patient populations tend to have higher rates of colonization than healthy adults. Almost all (>90\%) adult patients with atopic dermatitis $(\mathrm{AD})$ are $S$. aureus nares and/or skin carriers (27). Granulomatosis with polyangiitis (GPA - formerly Wegener's granulomatosis) patients also have higher rates of nasal S. aureus carriage (28). Other cohorts with recurrent skin breaches have higher carriage rates, including insulin-dependent diabetics, renal replacement therapy patients, and intravenous drug users, although the exact mechanisms are unclear (12). The rates among non-AD patients receiving injected allergen immunotherapy are not significantly higher than healthy controls, so perhaps repeated skin breaks alone are not sufficient to influence carriage (29). HIV-positive patients also appear to have more frequent nasal colonization, although there are many potential confounders which may explain this, including increased contact with healthcare, repeated anti-microbial exposures, tendency to develop skin disease, use of medical intravascular devices, and higher frequency of intravenous drug use. Nonetheless, even when corrected for degree of immunosuppression, viral load, and drug use, HIV remains an independent risk factor for $S$. aureus colonization for as yet undefined reasons $(30,31)$.

\section{THE RELATIONSHIP BETWEEN COLONIZATION AND INVASIVE DISEASE}

Nasal carriage of $S$. aureus is strongly associated with infection. Clinical studies consistently describe a significantly greater risk of bacteremia among carriers, quoting relative risks from 1.2 to 21.7 in cohorts with regular healthcare contact, especially in the presence of indwelling devices $(12,32-35)$. The majority $(>80 \%)$ of $S$. aureus nosocomial bacteremias are caused by invasion of the endogenous colonizing strain $(36,37)$. Nasal carriage has also been shown to increase non-bacteremic $S$. aureus healthcare-associated infections, again largely with endogenous strains (38-41). While it seems logical that persistent carriers would have a greater risk of infection than those with transient carriage, this has rarely been formally tested. A single study of 52 peritoneal dialysis patients attempted to answer this question by measuring exit site infections and peritonitis (42). For both outcomes, the relative risk of clinically evident $S$. aureus infection was ninefold higher among persistent carriers as compared with non-persistent carriers. In the community, where the burden of disease is SSTIs, the colonizing strain is also the causative agent (43). 
Colonization with methicillin-resistant S. aureus (MRSA) strains seems to confer a higher risk of subsequent invasion in hospitalized patients than methicillin-sensitive (MSSA) strains, although these patients may be inherently more complex with longer hospital stays and broader anti-microbial exposure (32, $44,45)$. A study which matched patients for MRSA nasal carriage found that those with multiple hospitalizations or a central venous catheter in situ were more likely to develop $S$. aureus bacteremia, which may explain the aforementioned findings (35). In MSSA bacteremia the presence of a central venous catheter does not seem to make a significant difference, and colonization seems to be the much greater risk factor (37). Carriage of the North American community-acquired methicillin-resistant (CA-MRSA) strains may be associated with higher risk of SSTIs than MSSA carriage $(46,47)$. This is perhaps not surprising as these strains are often armed with several toxins ideal for tissue destruction (48). It does not appear to translate into a worse outcome in bacteremia, however (49). While the rise in nasal colonization with USA300 in North America is remarkable, the expansion of epidemic clones is not a new feature in the history of $S$. aureus, and mechanisms by which particular strains may be better colonizers have not been ascertained $(50,51)$. Clonal distributions in other parts of the world remain diverse $(52,53)$.

Despite their increased risk of infection relative to non-carriers, only a tiny minority of nasally colonized individuals actually suffer any adverse effects from their co-existence with $S$. aureus. Even with conservative estimates, the incidence of carriage is 1000 times greater than that of serious invasive infection (54). Despite its armory of virulence factors, the energy and time of $S$. aureus is overwhelmingly directed, not at causing invasive disease, but rather in spreading from host to host to establish colonization.

\section{HOST FACTORS DETERIMINING S. AUREUS COLONIZATION}

Given the link between colonization and disease, strategies to prevent nasal colonization could be an appealing method of combatting S. aureus infection. In contrast to the multiple bacterial factors known to be involved in colonization ( see Figure 1), there is far less known about host elements and their relative contribution.

\section{ANATOMY AND ADHERENCE}

Staphylococcus aureus preferentially colonizes the vestibulum nasi. Autopsy studies have shown it residing within the squamous epithelial layer, associated keratin and mucous debris, and even within hair follicle shafts (55). Adherence of a laboratory S. aureus strain to the squamous cells of volunteers known to be naturally colonized is significantly greater than adherence to cells of non-carriers (56). Nasal secretions from human carriers also improve in vitro adherence, perhaps in part due to the presence of hemoglobin, which seems to inhibit agr expression (57).

During successful human colonization $S$. aureus preferentially expresses tissue-adherence and immune-evasion molecules and down-regulates virulence factors and toxins $(58,59)$. A number of microbial surface components recognizing adhesive matrix molecules (MSCRAMMs) have been shown to interact directly with the nasal epithelium. In particular clumping factor B (ClfB) and iron-regulated surface determinant A (IsdA) are factors thought to promote adhesion. Their host target ligands, however, are not as well-studied. ClfB adheres to cytokeratin $\mathrm{K} 10$ in vitro, and produces more successful experimental nasal colonization in humans (60). The key ClfB ligand in vivo is most likely loricrin. Loricrin is the most abundant protein in the keratinized epithelial layer of the nares. Binding of $S$. aureus to these human cells has recently been shown to be ClfB-dependent, and the absence of either loricrin or ClfB significantly impairs colonization in a murine model (61). This introduces the intriguing idea of blocking loricrin to inhibit colonization. Although born with skin abnormalities, due to multiple compensation mechanisms, loricrin deficiency in adult mice does not lead to significant phenotypic abnormality (62). Mutations in humans, however, are associated with significant diffuse skin disease (63). In the case of IsdA the human ligands involved are less clear and its effect on human colonization has not been convincingly demonstrated in vivo (64-66).

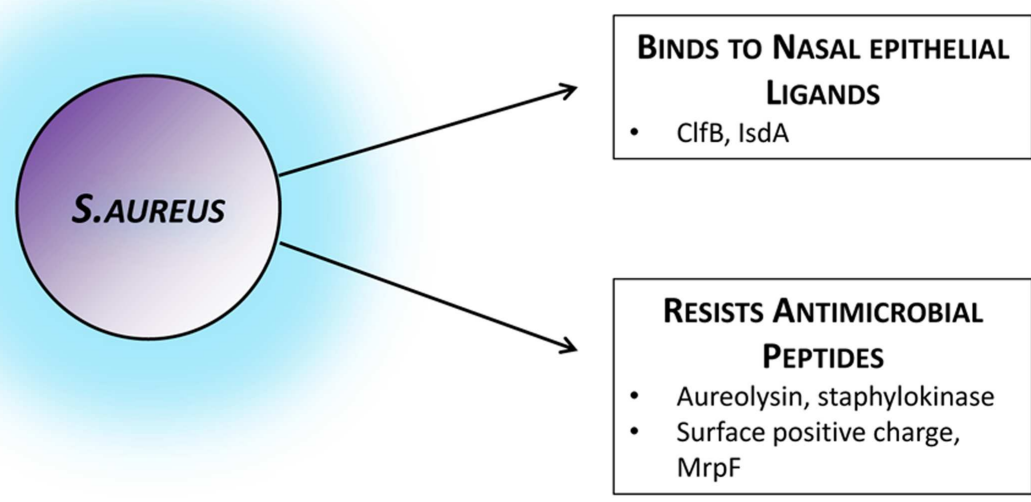

FIGURE 1 | Staphylococcus aureus factors facilitating colonization. Bacterial strategies and attributes known to facilitate colonization by mediating adhesion to the nasal epithelium or by actively evading host mechanisms of bacterial clearance. Those established in colonization settings and in vivo have been included, although several other immune-evasion mechanisms have been described in infection models or in vitro. ClfB, clumping factor $B$; IsdA, iron-regulated surface determinant $A$; MrpF, multiple resistance and $\mathrm{pH}$ regulation protein $\mathrm{F}$. 


\section{LOCAL HOST IMMUNE ENVIRONMENT MAY DETERMINE COLONIZATION}

The anti-microbial defense mechanisms of epithelial sites comprise a collection of host-defense lipids, peptides, and proteins produced by epithelial cells and immune cells recruited to the site (67). These have broad-spectrum anti-microbial activity and the ability to rapidly and directly kill organisms, and modulate the innate immune response (68). Some of these anti-microbial peptides (AMPs) have been shown to interact with $S$. aureus, but knowledge of their exact mechanisms of action and of their influence on nasal colonization is limited.

Nasal secretions from carriers contain higher concentrations of $\alpha$-defensins (human neutrophil peptides $1-3$ ) and human $\beta$ defensin 2, possibly as a consequence of the organism's presence (69). These secretions seem to be less damaging to S. aureus in vitro, and create a permissive environment for successful colonization (70). Human $\beta$-defensin-3 (hBD-3) is the peptide that seems to have the most potent anti-S. aureus effect in vitro and in skin infections (71-73). Its production from skin and nasal secretions is normally driven by the presence of $S$. aureus or by disruption of the skin barrier, implying it may have a role in clearance of $S$. aureus in both colonization and infection (74, 75). Its constitutive and induced levels in skin are significantly lower in persistent carriers as compared to non-carriers, and this pattern has recently been associated with DEFB1 gene promoter polymorphisms $(76,77)$.

The multifunctional cutaneous cathelicidin LL-37 is impressively effective at in vitro killing of both extra- and intra-cellular $S$. aureus $(78,79)$. Despite this, in a single small study which included GPA patients, the nasal secretions of those colonized with S. aureus contained higher concentrations of LL-37 than non-colonized participants, and its production was induced by stimulation with $S$. aureus (75). The significance of this for the healthy population is unclear. The cathelicidin gene carries a vitamin D response element, and vitamin D increases expression and function of many AMPs $(80,81)$. An inverse association between vitamin D levels and $S$. aureus nasal carriage has been found in epidemiological studies $(82,83)$. However, vitamin D supplementation does not reduce persistent carriage in healthy adults (84). Host-derived lipids from sinuses and skin also exhibit anti-microbial properties (85-88). Several other peptides have been found to have anti-S. aureus activity but their role in colonization has not been assessed (89).

Some defects in local anti-microbial activity have been described in the skin of highly colonized populations. The skin surface of AD patients with particular filaggrin mutations is less acidic than healthy skin and exhibits inhibited AMP activity. In vitro experiments show increased $S$. aureus growth and expression of adherence and immune-evasion molecules under these conditions (90). Hexadecenoic acid and free sphingosine lipids are present at lower levels in skin of AD patients than healthy controls $(91,92)$. It is not clear if these skin defects are mirrored in the nasal epithelium or contribute to their higher nasal carriage rates. In GPA patients, aberrancies in baseline nasal mucosal cytokine expression and altered nasal epithelial AMP responses to $S$. aureus have been described but it is not known if this explains their increased colonization $(75,93)$.
The organism must overcome these local immune challenges if it is to persistently colonize. Unfortunately, S. aureus has adapted to this system by producing proteases to degrade AMPs, proteins to bind, and inactivate them, and by altering the charge of its cell wall to reduce their affinity to attach (94).

\section{THE INFLUENCE OF HOST GENETICS ON NASAL COLONIZATION}

In addition to the defensin gene polymorphisms mentioned above, several other mutations have been associated with nasal carriage. Interleukin-4 (IL-4), mannose-binding lectin, toll-like receptor 2 (TLR2), glucocorticoid receptor gene, and C-reactive protein polymorphisms have all been linked to carriage, as has HLA-DR3 (69, 95-97). The identified IL-4 polymorphism causes lower levels of IL-4, resulting in reduced mucin production and dampening of the Th2 response $(98,99)$. In a sample of elderly Dutch patients, the glucocorticoid receptor polymorphism found in persistent carriage was associated with a phenotype of putative high cortisol levels causing immunosuppression, and the non-carriage haplotype was thought to reflect reduced immunosuppression (100). Mechanistic explanations are not apparent for the other genetic traits to date.

Instead of interrogating for single genes, some studies have looked for individuals likely to share multiple genetic similarities to ascertain the role of host genome in colonization. Persistent carriage patterns were not concordant among same-sex siblings or even among twin pairs, regardless of gender or zygosity $(101,102)$. The fact that no strongly convincing genetic trait has accounted for successful or unsuccessful colonization indicates that it must be determined by multiple factors that may even differ from carrier to carrier.

\section{EXPANDING THE "HOST" CONCEPT - IMPACT OF THE MICROBIOTA ON HOST IMIMUNITY}

Colonization with microorganisms begins during birth and continues throughout early life, such that each human is rapidly outnumbered by the diverse microbial community they carry. Where S. aureus is part of the nasal flora in particular individuals, it does not exist in isolation. The normal microbial population of humans is rapidly being characterized, and we share our upper airways with bacteria, fungi, and viruses - many of which are potentially pathogenic - during periods of both good and ill health (103-106). Some colonizing organisms at other sites may confer metabolic and/or immune benefits to their host, and dysbiosis may be associated with disease. Resident microbes have complex interplay, and can signal between species and across kingdoms, as well as directly modify host immune responses.

\section{"INTERFERENCE" BETWEEN S. AUREUS AND NEIGHBORING RESIDENT MICROBES}

The bacterial community of the nares in adults is variable, but dominated by Corynebacterium, Priopionibacterium, and Staphylococcus species $(107,108)$. The interaction between the host and each microbial species in the nares is also influenced by the other competing microorganisms present.

Traditionally, a resident $S$. aureus strain is thought to "hold fast" in its niche, whether by specific adherence factors or simply by physical occupation of space. It then resists later acquisition of 
different strains or even of the same strain $(109,110)$. This view has been somewhat challenged by more recent molecular methods showing that a minority of $S$. aureus-colonized individuals can carry more than one strain at a time or acquire new displacing S. aureus strains $(22,111,112)$.

This "first-come-first-served" approach is also observed in its interplay with other staphylococcal species. Staphylococcus epidermidis colonizes almost $100 \%$ of humans, often with multiple strains concurrently (113). S. aureus carriage is negatively associated with S. epidermidis and P. acnes in adults (107). Resident $S$. epidermidis reduces but does not prevent $S$. aureus colonization in animal models following elimination of their original nasopharyngeal flora. This interplay may be due to genus-specific blocking of virulence gene expression, whereby agr auto-inducing peptides can act as inhibitors of quorum-sensing in a different staphylococcal strain or species $(114,115)$. Application of strains of $S$. epidermidis secreting the serine protease Esp inhibit $S$. aureus colonization in vivo and eliminate human nasal $S$. aureus carriage in pilot studies in vitro (116). This concept of inter- and intraspecies bacterial interference is long-known, and appears most powerful between species of the same genus, as they often compete for the same ecological niche. In the 1960s, when a number of serious $S$. aureus epidemics occurred in hospital nurseries, it was noted that pre-existing colonization of the nasal mucosa or umbilical stump of infants prevented subsequent colonization by the epidemic strain. This observation led to the deliberate inoculation of neonates with a "low-virulence" S. aureus 502A strain that obviated colonization with the emerging penicillin-resistant strains and resulted in significant decreases in invasive $S$. aureus disease (117).

Other resident species in the nose behave quite differently. Streptococcus pneumoniae and Haemophilus influenzae strains acquired at different times can co-exist with the original species, and tend to have more transient periods of carriage $(110,118)$. Some studies show an inverse relationship between $S$. aureus and S. pneumoniae, but only in children and the association is not consistent (119-121). A mechanism has been proposed to explain this interspecies competition. Pneumococci produce sufficient hydrogen peroxide to induce a stress response and activate resident $S$. aureus lysogenic prophages. This results in staphylococcal cell lysis and death in vitro (122).

The nares have a temporally stable microbiota. Bacterial ecology is altered during the course of systemic antibiotic treatment, and intercurrent upper respiratory tract infections, but these alterations are short-lived $(106,123)$. Similarly, attempts to decolonize patients by using intranasal mupirocin and/or topical chlorhexidine is not a reliable strategy for long-term elimination, although it may decrease immediate risk of surgical site infections (124, 125). Repeated application of Corynebacterium species to the nares of persistent $S$. aureus carriers results in clearance for a variable period of time, and actively ingested probiotics fail to significantly alter S. aureus nasal carriage $(126,127)$.

Such "interference" is not confined to co-existing bacteria. Synergistic and antagonistic signaling may occur between kingdoms of normal flora. In murine infection models, co-infection with Candida albicans synergistically enhances virulence and mortality in systemic S. aureus infection (128). This is associated with an increase in pro-inflammatory cytokines and end-organ cellular infiltrates indicating fungal-bacterial modulation of host innate immune response (129). Conversely, the candidal quorum-sensing molecule farnesol inhibits $S$. aureus biofilm formation and compromises cell membrane integrity in vitro (130). Such modulatory cross-kingdom signaling is not well understood during asymptomatic in vivo colonization. Nevertheless, the prospect of altering the local constituents of the nasal microbiota to direct $S$. aureus colonization is tantalizing.

\section{THE IMPACT OF THE MICROBIOTA ON IMMUNE DEVELOPMENT}

The microbiota is overwhelmingly comprised of anaerobic bacteria residing in the distal gastrointestinal tract, although all mucosal surfaces are colonized with various microorganisms. Most knowledge of the interactions between colonizing organisms and host immunity relates to the intestinal microbiota. Colonization with these organisms provides benefits to the host by adding metabolic function and preventing pure pathogen overgrowth, but many gut microbes are also potentially pathogenic. Containing the growth of the vast number of "non-self" microbial cells in contact with the intestinal epithelium is a significant challenge to host immunity, but responding with over-zealous inflammatory activity results in host damage. Thus, while immune response must be present for health, it must also be tightly regulated and directed in a way appropriate to each tissue or organ site.

Induction and maintenance of immune tolerance to commensal intestinal organisms is essential to normal local and systemic lymphoid maturation (131-133). The microbiota orchestrates the differentiation and homeostasis of various $\mathrm{T}$ cell subsets in animals. It regulates development of pro-inflammatory intestinal Th17 cells, and anti-inflammatory regulatory T cells (Tregs) both in the intestine and systemically (134). Tregs are greatly reduced in germ-free animals, and this depletion results in detrimental inflammation due to expansion of unopposed microbe-specific pro-inflammatory T helper subsets $(135,136)$. Conversely, in skin, commensals normally drive pro-inflammatory tissue-resident $\mathrm{T}$ cells preferentially, and germ-free animals have greatly increased numbers of skin Tregs (137).

Much less is known about the mechanisms and outcomes of microbial immunomodulation in humans, but our host immune responses may also be manipulated to favor a colonizer's persistence. Co-culture of human peripheral blood mononuclear cells (PBMCs) with species of Lactobacillus and Bifidobacterium show differences in the induction of Tregs specific to those species (138). C. albicans produces prostaglandins that reduce lymphocyte proliferation, TNF- $\alpha$ and chemokine production while upregulating IL-10 production in mammalian cells (139). Such immunomodulation of effector and Treg response mechanisms by intestinal microbes has also been implicated in protecting against development of systemic allergic and autoimmune disorders (140-142).

\section{THE IMPRINT OF THE MICROBIOTA ON HUMAN ADAPTIVE IMMUNITY}

In animals with controlled mucosal exposure to gut commensal antigens, the development of specific immune responses is limited to the mucosal and local mesenteric lymphoid organs without spread to secondary lymphoid organs or development of systemic 
immunity (143). T lymphocytes are essential to this compartmentalized response and their depletion results in systemic microbial translocation (144).

While in a tolerant co-existence with the microbiota, humans nonetheless often develop a systemic adaptive immune response to these organisms, perhaps as a result of transient bacteremias due to such microbial translocations. Circulating antibodies to commensal microbial antigens including C. albicans, Escherichia coli, Clostridium difficile, Neisseria, and Bacteroides species are common in healthy individuals (145-149). These antibody responses are significantly elevated in some cases of chronic or acute intestinal barrier disruption (150-152). Adaptive cellular responses are also normally produced, with small numbers of $E$. coli-specific Th1 cells present in the peripheral blood of healthy individuals (153). Experimental gastroenteritis and subsequent translocation of intestinal bacteria enhances systemic microbiota-specific memory Th1 cell development (154). Despite the presence of these primed $\mathrm{B}$ and $\mathrm{T}$ lymphocytes, they are not associated with ongoing uncontrolled systemic inflammatory responses in the absence of invasive infection. Instead, the compartmentalized mucosal immune response tolerates but tightly confines the intestinal microbiota to its appropriate site. Much less is known, however, about the impact of the microbiota at other sites on local and systemic immune response.

\section{SITE-SPECIFIC ADAPTIVE IMMUNITY}

The establishment and maintenance of balanced interactions between the host and its microbiota seem a key requirement for health, but little is known about the unique immunomodulation by most pathobionts in humans. Understanding these mechanisms and translating the findings into therapeutic interventions remains a major challenge but an attractive avenue for future vaccine development. Both pro- and anti-inflammatory antigen-specific lymphocytes may be induced by bacterial colonization of extraintestinal sites as well. The polarization and efficacy of these cells may in fact be completely dependent on the site or compartment at which they first encounter the immune system. In an animal model of Listeria monocytogenes infection, for instance, intravenous inoculation drives the development of systemic long-lived Th1 effector memory cells, whereas intranasal infection with the same organism drives short-lived central memory Th17 cells (155).

In humans, this concept of site-specific adaptive immunity has been elegantly explored in the case of S. pneumoniae. Various pneumococcal-specific T cells in humans - Th1, Th17, Tregs are much more numerous in tonsillar lymphoid tissue close to the site of colonization, than in the peripheral blood (156). Similar mucosal Th17 responses to experimental colonization are seen in mice and humans, and this protects against subsequent colonization in both $(157,158)$. Human tonsillar lymphocytes produce pro-inflammatory IL-17A in response to pneumococcal antigens, which improves in vitro phagocytic killing of the organism (159). In contrast, adenoidal tissue of children naturally colonized with S. pneumoniae shows increased proportions of IL-10secreting pneumococcal-specific Tregs, which inhibit CD4 ${ }^{+}$proliferation and production of pro-inflammatory cytokines (IFN $\gamma$, TNF- $\alpha$, and IL-17A) (160). The relative proportions of pro- and anti-inflammatory $\mathrm{T}$ cells specific to S. pneumoniae in tonsillar lymphocytes are roughly equal. These local immunomodulatory Tregs may thus reduce inflammation-related airway damage during infection, but facilitate the persistence of pneumococcal carriage.

In peripheral blood lymphocytes, the picture is very different. The circulating immunosuppressive Treg phenotype is far less evident and the balance is overwhelmingly skewed in favor of Th1 and/or Th17 cells $(156,159,161)$. This compartment is primed toward a rapid pro-inflammatory cellular response, and also has ready circulation of anti-pneumococcal antibodies, both of which are critical for efficient bacterial clearance in invasive disease. This shows that the bias of appropriate host response is site-specific, and anti-pneumococcal cells' function and mechanisms of protective immunity may also vary by site. Normal host response is tailored to a balanced tolerance at sites normally colonized by commensal organisms, and rapid attack at normally sterile sites. This tightly regulated balance between pro- and anti-inflammatory responses to $S$. pneumoniae seems to greatly influence the outcome of colonization and perhaps even that of infection $(157,162)$.

Such site-specific characterization of local and systemic immune response to colonization, and exploration of the relative importance of these in the prevention of invasive disease have only been minimally elucidated for $S$. aureus to date and are further discussed below.

\section{THE EFFECT OF S. AUREUS COLONIZATION ON THE HOST IMMUNE SYSTEM}

In the battle between microbe and host during infection, many $S$. aureus attributes that contribute to its virulence and lethality have been described, but much less is known about the host's defense or breaching of this defense. Where this has been studied it is usually in the context of invasive disease, hence there is extremely limited knowledge of host response during asymptomatic periods of colonization. Critical questions remain unknown. Are there particular protective actions preventing colonization? What host immune failures occur to allow invasion? And does the immune imprint of colonization affect subsequent response to invasive infection?

\section{THE INFLUENCE OF COLONIZATION ON OUTCOME OF INFECTION - A HINT THAT COLONIZATION MATTERS?}

Colonization is known to substantially increase the risk of subsequent infection, and invasive $S$. aureus disease carries a high mortality rate. On the other hand, it is clear that being a carrier alone - like a large proportion of the healthy population - does not cause death or other adverse consequences in the absence of infection. It is unknown whether host immunological adaptation to the colonizing strain in nasal carriers confers any advantage or disadvantage in recovery from active infection.

One notable large-scale Dutch study retrospectively examined the incidence of nosocomial S. aureus bacteremia and mortality in carriers (persistent and/or transient) vs. non-carriers in a 120-day follow-up period (37). As expected it showed a higher incidence of bacteremia among carriers, although all-cause or infectionattributable mortality was not significantly different between both groups ( 0.1 vs. $0.1 \%$; $p=0.81$ for $S$. aureus-attributable deaths). However, when the subset who did develop nosocomial bacteremia 
were analyzed independently, carriers appeared to have a lower allcause and $S$. aureus-attributable mortality (18 vs. $47 \%$; $p=0.005$ and 8 vs. $32 \% ; p=0.006)$. Severity of disease and incidence of septic shock were not reported. The carrier group were significantly younger and had fewer cardiac issues, which may explain their more favorable outcomes. Intriguingly, however, there may have been a key difference in their immune responses. The carriers were a more "immunocompromised" group (35 vs. $12 \%$; $p=0.02$ ) although this is unfortunately not further defined - which may have globally dampened potentially harmful "over-zealous" innate and adaptive responses in the setting of sepsis. Alternatively, they may have had a more appropriate or well-orchestrated specific response to invasive disease, given their prior exposure and a degree of potential immune tolerance to $S$. aureus.

A meta-analysis looking at the few observational studies that have examined the association between pre-morbid S. aureus colonization and mortality showed that carrier status showed a similar non-significant trend in reducing mortality directly attributable to the infection (163).

The immune mechanisms induced by colonization that might result in such improved outcomes following infection are not defined, although some clues exist. In humans, high titers of antiTSST-1 seem to be protective against staphylococcal toxic shock syndrome in that the disease seems to occur in those without protective anti-TSST antibodies (164). Persistent nasal carriers have higher titers of neutralizing antibodies to several superantigens (sAgs) that significantly reduce $\mathrm{T}$ cell proliferation and activation (165). This may lower their risk of developing toxic shock syndrome or attenuate the severity of sepsis. Higher levels of antibodies against several $S$. aureus toxins just prior to or at the onset of infection decreases the likelihood of developing sepsis during bacteremia, and although pre-morbid colonization was not formally assessed, the patients with improved outcome had a history of S. aureus infections (166). Establishing whether there is any association between the immune imprint of $S$. aureus colonization and the mortality attributable to this infection is critical for orchestrating and predicting response to infection and vaccines in future patients.

\section{HUMORAL RESPONSE TO $S$. AUREUS COLONIZATION}

Recognition and handling of $S$. aureus by the innate immune system is notable and has been outlined elsewhere (167-169). This type of immunity is currently considered to lack specific memory, and thus is not as attractive a target as the adaptive immune system for vaccine research (170). Humoral immunity is more enticing and established, but there a number of caveats against its promise in the case of $S$. aureus. B cell deficiencies in humans are not associated with increased infection rates, and do not worsen outcomes in animal challenge models (171-173). S. aureus is uniquely armed with protein A to eliminate antibodies formed against it by binding to their Fc $\gamma$ domain and by interacting with B cells to ultimately cause their anergy and apoptosis (174-176). This leads to a compromised adaptive immune response against other S. aureus antigens. Serum antibodies certainly seem to have functional antibacterial behaviors in vitro, but there may well be other staphylococcal products inhibiting optimum antibody activity in vivo $(177,178)$.
Frequent exposure to $S$. aureus does indeed imprint a memory antibody response in the host, although to a varying extent. The mechanism of induction of antibodies by colonization is not established. Transient bacteremias, self-resolving minor infections or absorption of toxins across the mucosa could directly explain systemic immune exposure to microbial antigens (179). Colonization alone less easily explains the production of adaptive immune memory. It only results in antibody formation to a limited selection of the $S$. aureus antigens known to be present, and experimental nasal colonization in humans does not induce significant humoral changes $(180,181)$.

Whether antibodies are implicated in preventing colonization by inhibiting adherence, facilitating immediate clearance, or other unknown methods - is also undetermined. It is clear that transplacental transfer of a lifetime's collection of maternal anti-S. aureus IgG does not protect infants from colonization in infancy, nor does the development of their own anti-S. aureus antibodies prevent subsequent colonization $(182,183)$. Most adults and children have a variable degree of anti-S. aureus antibodies of various classes present in serum, whether colonized or not $(178,183,184)$. Local antibodies in the nares are less studied although show some correlation with systemic titers (178).

Different studies have found lower or higher levels of antibodies against $S$. aureus antigens among nasal carriers and non-carriers $(64,177,178,182,184)$. The overwhelming trend is of considerable inter-individual variation, and findings are often contradictory. Consistently reproducible key patterns of antibody titers or differences in functionality between carriers and non-carriers have not been shown. Unfortunately, not all studies have rigorously identified true persistent carriers before drawing conclusions about differences in antibody levels, and those that have may be more reliable $(11,178,180)$.

Some animal studies have shown antibody-based interventions to prevent $S$. aureus colonization. Production of antibodies to IsdA or IsdH prevented nasal colonization of cotton rats, but only when a lower bacterial inoculum was used (64). Intranasal immunization of mice with recombinant $\mathrm{ClfB}$ or systemic administration of anti-ClfB monoclonal antibody reduced bacterial load but did not prevent colonization (185). Immunization to prevent colonization in humans has not been tested.

Whether in infection or colonization, antibody patterns are extremely diverse and it is difficult to discern clear patterns. Of course, only a fraction of the antigens in $S$. aureus's protein and polysaccharide repertoire have been evaluated for antibody response thus far, and perhaps combining patterns of multiple antibodies may better discriminate between groups. Nonetheless, even patients infected or colonized with genetically similar organisms produce unique responses (186). This further supports the theory of a uniquely personalized host-microbe relationship dependent on the temporal history of exposure, number, and genetic diversity of strains and intrinsic adaptive host response.

\section{ADAPTIVE CELLULAR IMMUNE RESPONSE TO $S$. AUREUS COLONIZATION}

Evidently, colonization - or perhaps more accurately transient microinvasions or other exposures to S. aureus - influences systemic antibody repertoire. It is equally likely that this history 
of exposure induces adaptive cellular immune responses, and of course $\mathrm{T}$ helper cells are essential for optimal B cell activity. There is extremely limited data on this in the case of $S$. aureus colonization.

Early intestinal colonization with $S$. aureus in children is associated with increased numbers of systemic IL- 4 and -10 producing cells (187). It may also predict a higher likelihood of atopic disease (188). Airway exposure to $S$. aureus enterotoxins has been linked to the development of asthma and allergic rhinitis, perhaps by inducing local Th1/Th17 responses (189-191).

T cells in nasal lymphoid tissue mediate clearance of $S$. aureus from nasally inoculated mice. This decolonization is dependent on the Th17 response and facilitated via IL-17A and its associated neutrophil influx (192). Unlike humans, mice are naturally somewhat resistant to nasal colonization, and further understanding of these Th17 responses could be used to develop interventions to reduce or understand human colonization. The mechanisms of local and systemic cellular responses to nasal colonization and their relative importance in the prevention of invasive disease have not been fully elucidated for $S$. aureus to date, although some evidence points to suppression of local pro-inflammatory signals facilitating persistent colonization (193-195). A proposed mechanism for nasal carriage and resistance to carriage is presented in Figure 2.

\section{THE IMPORTANCE OF T CELLS IN S. AUREUS INFECTION AND THEIR MODULATION OF IMMUNITY}

Some animal and preliminary human data has proposed an important role for various $\mathrm{T}$ cells in dealing with certain $S$. aureus infections. However, as discussed above, human exposure to the organism long prior to an episode of infection will likely determine the nature of the $\mathrm{T}$ cell response re-activated during later disease. Understanding how T cells are "primed" during colonization is fundamental to manipulating their activity for adjunctive treatment or vaccination.

\section{THE ROLE OF T CELLS IN ANIMAL MODELS OF S. AUREUS INFECTION}

In murine wound infection models, $\mathrm{T}$ cell deficient mice exhibit lower concentrations of CXC chemokines in local tissue due to a reduction in lymphocyte-derived IFN- $\gamma$ (196). This results in less trafficking of $\mathrm{CD}^{+}$cells and neutrophils to the site, reduced inflammation, and lower bacterial burden (197). Absence of gamma-delta $\mathrm{T}$ cells producing IL-17A also leads to a similar phenotype $(198,199)$.

In systemic infection $\mathrm{T}$ cells appear to be crucial to survival with rapid mortality following intravenous challenge in $\mathrm{T}$ cell knockout mice (173). Th1 and Th17 subsets seem most critical, and both IFN- $\gamma$ and IL-17 are routinely produced during systemic infection (200). Deficiency in IFN- $\gamma$ but not IL-17A results in increased

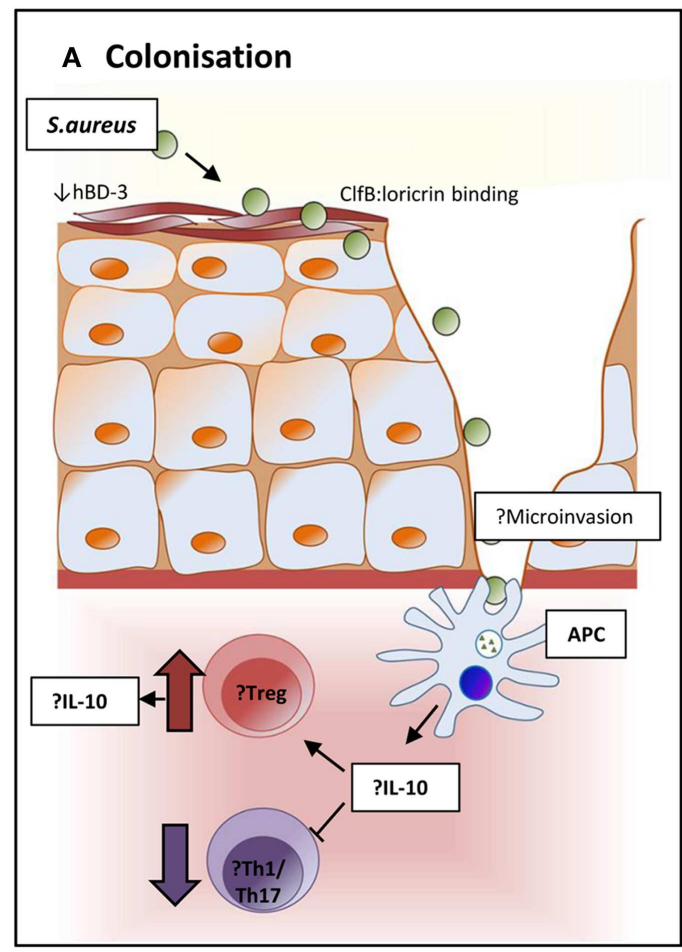

FIGURE 2 | Proposed immunomodulation affecting and resulting from colonization in persistent and non-persistent carriage. (A) The epithelium and local environment of the nares in individuals with $S$. aureus carriage may be more favorable for colonization with high levels of host ligands to facilitate adhesion, and reduced concentrations of the potent anti-staphylococcal peptide human $\beta$-defensin 3 (hBD-3) in nasal secretions. Interaction and processing of $S$. aureus by local antigen-presenting cells may result in an

\section{B Non-colonisation}

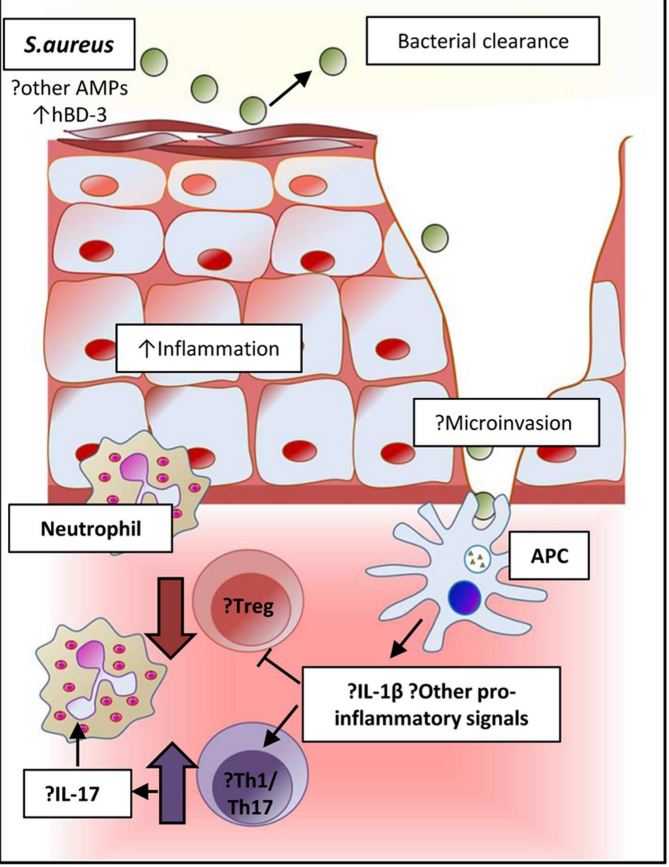

immune tolerance and suppression of pro-inflammatory responses. Inhibition of bacterial clearance would allow persistent colonization. (B) In non-carriers, the local environment and response might resist successful $S$. aureus colonization. Nasal secretions may contain higher levels of hBD-3 or other anti-microbial peptides. Local immune response to the organism could be more pro-inflammatory and promote the expansion of Th17 cells to attract neutrophils and create local inflammation that facilitates bacterial clearance. 
mortality $(201,202)$. However, Th17 expansion may be essential to effective vaccine responses $(202,203)$.

\section{THE ROLE OF T CELLS IN HUMAN S. AUREUS INFECTION}

With the exception of the superantigens, few S. aureus-specific T cell epitopes have been identified, and the normal human $\mathrm{T}$ cell response to this organism has had negligible evaluation (204-207). There have been no human studies examining the role of T helper cells in $S$. aureus colonization or invasive infection, but there are some clues as to the importance of $\mathrm{T}$ cells in human $S$. aureus disease.

Particular T cell subsets have been implicated in intact cutaneous and mucosal immunity to $S$. aureus. A heterogeneous group of disorders may cause the chronic mucocutaneous candidiasis (CMC) syndrome, which is characterized by integumentary $\mathrm{T}$ cell hypo-responsiveness to C. albicans antigens (208). These patients suffer from protracted $C$. albicans and $S$. aureus mucocutaneous infections. Inborn errors of Th17 cells seem to underlie CMC $(209,210)$. Patients with the rare autosomal dominant hyper-IgE syndrome (AD-HIES) are prone to $\mathrm{CMC}$, and to staphylococcal skin and lung abscesses along with other abnormalities $(211,212)$. Mutations in the signal transducer and activator of transcription 3 (STAT3) gene account for the majority of cases (212). STAT3 is involved in the signal transduction of several pro- and antiinflammatory cytokines, and stimulation of PBMCs from these patients shows increased secretion of TNF- $\alpha$ and IFN- $\gamma$ (213). Naïve $\mathrm{CD}^{+}{ }^{+} \mathrm{T}$ cells with this mutation fail to differentiate into Th17 cells, but retain the ability to differentiate into other subsets $(214,215)$. Interestingly these patients do not seem more prone to $S$. aureus bacteremias despite their global systemic Th17 deficiency. This may be explained by differences in site-specific immune response. Unlike cells from other sites, human skin and respiratory epithelial cells seem to require the synergistic stimuli of both Th17-derived and classical pro-inflammatory cytokines for enhanced production of AMPs (h- $\beta$ D-2 and -3) and neutrophil chemotaxins (216).

HIV-infected individuals are also commonly affected with recurrent skin and mucosal infections, frequently caused by $C$. albicans and S. aureus. Of all $\mathrm{CD}^{+}{ }^{+}$cells, HIV-positive patients preferentially show profound loss of circulating Th17 cells, even at early disease stages $(217,218)$.

Th17 cells thus seem essential for intact mucocutaneous immunity to extracellular bacteria and fungi. Specific T cell responses in infections of other sites are less well understood.

\section{T CELL IMMUNOMODULATION INDUCED BY S. AUREUS AND ITS EFFECTS}

The multiplicity of mechanisms utilized by $S$. aureus to evade the innate immune system and cause infection are staggering (219). Its means of skirting the adaptive immune system are less well appreciated but its ability to delete or block development of evidence of its presence must surely contribute to the lack of an effective immunological memory. Invasive S. aureus infections are associated with decreased transcription of genes relating to adaptive immunity and increased expression of myeloid and innate immunity genes $(220,221)$. Several microbial factors are known to directly interact with lymphocytes (Table 1).

Secreted or wall-anchored staphylococcal protein A binds IgG in the incorrect orientation for neutrophil recognition and thus inhibits opsonophagocytosis. It also binds to the $\mathrm{V}_{\mathrm{H}} 3$ region of IgM on the surface of B lymphocytes, initiating a B cell receptormediated programed cell death that results in significant depletion of the reservoir of potential antibody-producing cells (174). The presence of an array of superantigenic toxins directly activates vast numbers of T cells, but this is followed by the loss of these cells' ability to respond to these antigens (anergy). This prevents normal development - via MHC Class II/TCR presentation of processed antigens - of true microbial antigen-specific effector and memory cells (226). At least one of these superantigens is expressed by most circulating clinical isolates $(223,227)$. The MHC Class II analog protein (Map) is a secreted $S$. aureus protein with similarity to the MHC peptide-binding groove. Its binding reduces lymphocyte proliferation and shifts this response in a Th2 direction, thus suppressing the Th1 responses shown to be important for bacterial clearance in animal systemic infection (228). CCR5 on the surface of macrophages and T lymphocytes appears to be necessary for Leukotoxin ED (LukED) to produce pore-forming cytotoxicity, and absence of either host CCR5 or staphylococcal

Table 1 | Staphylococcal factors implicated in directly modulating the host adaptive immune response.

\begin{tabular}{|c|c|c|c|c|}
\hline $\begin{array}{l}\text { Immunomodulatory } \\
\text { factor }\end{array}$ & $\begin{array}{l}\text { Prevalence in } \\
\text { clinical strains }(\%)\end{array}$ & $\begin{array}{l}\text { Evidence for activity } \\
\text { in colonization }\end{array}$ & Human target & Effect \\
\hline Protein A (Spa) & $91(222)$ & $\begin{array}{l}\text { Mostly transcribed in } \\
\text { persistent carriers }(58,222)\end{array}$ & $\begin{array}{l}\text { (i) } \mathrm{Fc} \text { region free } \operatorname{lgG} \text {; } \\
\text { (ii) } \mathrm{B} \text { cell-surface } \operatorname{lgM} \\
\mathrm{V}_{\mathrm{H}} 3 \text { region }\end{array}$ & $\begin{array}{l}\text { (i) Inhibits opsonophagocytosis; } \\
\text { (ii) programed B cell death }\end{array}$ \\
\hline $\begin{array}{l}\text { Superantigens (staphylococcal } \\
\text { enterotoxins and toxic shock } \\
\text { syndrome toxins) }\end{array}$ & 73 (223) & $\begin{array}{l}\text { Variably transcribed during } \\
\text { carriage (181) }\end{array}$ & MHC Class II & $\begin{array}{l}\text { Binds } \mathrm{MHC} \text { Class } I I \text { to the } T \text { cell } \\
\text { receptor to cause initial activation } \\
\text { followed by anergic unresponsiveness }\end{array}$ \\
\hline $\begin{array}{l}\text { MHC Class II analog protein } \\
\text { (Map) }\end{array}$ & $94(222)$ & Unknown & $\begin{array}{l}\text { MHC peptide-binding } \\
\text { groove }\end{array}$ & $\begin{array}{l}\text { (i) Reduced lymphocyte proliferation; } \\
\text { (ii) Th2-predominant response }\end{array}$ \\
\hline Leukotoxin ED & $30-87(224,225)$ & Unknown & $\begin{array}{l}\text { CCR5 (T lymphocytes } \\
\text { and macrophages) }\end{array}$ & $\begin{array}{l}\text { Cell membrane pore formation causing } \\
\text { cytotoxicity }\end{array}$ \\
\hline
\end{tabular}


LukED results in lower levels of pro-inflammatory cytokines and markedly reduced mortality in systemic infection models (229). However, these factors have largely been shown in animal infection models or in vitro, without necessarily simulating physiological concentrations. More importantly, none of them have been exclusively examined for their immunomodulatory effects in the setting of colonization.

The balance between pro-inflammatory and anti-inflammatory adaptive responses required for controlled but successful bacterial clearance and clinical recovery are unknown, as is whether or not colonization influences this balance. Repeated or prolonged $S$. aureus encounters may lead to an altered and even immunosuppressive response to its antigens at certain sites.

Children with $\mathrm{AD}$ and $S$. aureus skin colonization have globally reduced IFN- $\gamma$ production from $\mathrm{CD} 4^{+}$PBMCs in response to non-specific stimulation, particularly those with higher bacterial loads (193). This finding may, of course, be more to do with the underlying disease than the organism. Human monocyte-derived IL-10 has been experimentally shown to reduce development of pro-inflammatory Th1/Th17 responses in vitro (230). This inhibitory response is far less dramatic when dendritic cells are the antigen-presenting cells (APCs), which may support the sitespecific concept of aggressively responding to invasion of normally sterile sites like the bloodstream. Using monocytes to prime naïve human T cells with heat-killed $S$. aureus produces antigen-specific populations of Th1 and Th17 "pro-inflammatory" cells. However, persistent restimulation of these $S$. aureus-specific Th17 cells results in a switch to an "anti-inflammatory" phenotype - reduced IL-17 and increased IL-10 production. The same pattern was seen in S. aureus-specific human memory Th17 and Th1/Th17 cells (231). These immunomodulatory responses may occur upstream of the adaptive response, as interactions of the innate immune system with $S$. aureus produce cytokines to polarize T cell production and memory responses. For instance, staphylococcal peptidoglycan uses TLR2 signaling to induce IL-10 production and apoptosis of human APCs (232).

Similar immune "switching" is seen in animals after exposure, where these effects can then be evaluated in infection challenge experiments. Persistent systemic exposure to $S$. aureus in mice also leads to in vivo $\mathrm{T}$ cell clonal anergy and immunosuppression which may be IL-10 mediated (233-236). Intraperitoneal vaccination of naïve mice with heat-killed $S$. aureus switches their cytokine pattern on subsequent intravenous challenge. They show decreased IL-17, unchanged IFN- $\gamma$, and increased IL-10 production, as compared with unvaccinated mice (200). Staphylococcal peptidoglycan exposure increases plasma IL-10 and reduces IFN- $\gamma$ and TNF- $\alpha$ concentrations in response to intravenous bacterial challenge even in the absence of intact TLR2 signaling. Such "primed" immune-tolerant mice repeatedly demonstrate improved bacterial clearance and significantly reduced mortality in systemic $S$. aureus disease $(98,232,237)$.

It could be proposed that inducing a degree of $S$. aureus-specific immunosuppression may be a useful defensive adaptation against the pro-inflammatory "cytokine storm" that would be expected if superantigen-provoked massive $\mathrm{T}$ cell activation was allowed to go unopposed. It is remarkable that despite the prevalence and transcription of multiple superantigens in clinical infections, toxic shock syndrome is much more rarely observed than S. aureus bacteremia (223). Staphylococcal superantigen stimulation induces both TCR-mediated clonal anergy and Tregs producing IL-10 (235, 238). Rather than being protective, however, high levels of serum IL-10 at presentation in S. aureus bacteremia patients strongly predicts their mortality, although this is a relatively crude measurement and its cellular source or specificity in this setting is not determined (239).

Successful colonization in mice seems to be facilitated by an immunosuppressive predominance, and clearance dependent on developing specific pro-inflammatory (Th17) responses. Colonization in humans may mirror this pattern. The effects colonization has on innate immune signaling, polarization of systemic adaptive immunity, and whether these influence clinical outcome during subsequent infections is completely unknown. Closing these knowledge gaps is essential to developing an effective vaccine.

\section{ANTI-STAPHYLOCOCCAL VACCINE DESIGN IS COMPLICATED BY COLONIZATION}

An effective vaccine to prevent $S$. aureus disease remains elusive. Mathematical models conclude a vaccine of even relatively limited efficacy $(\leq 10 \%)$ would significantly decrease the incidence of invasive disease and be extremely cost effective in high-risk populations (240-242). Some important points on colonization's impact on immunity and the challenges of producing such a vaccine are illustrated in the most important human studies to date.

\section{CONSIDERATION OF COLONIZATION IN IMPORTANT HUMAN ANTI-S. AUREUS VACCINE STUDIES TO DATE}

Passive and active immunization strategies have been evaluated to prevent occurrence of or improve outcome of $S$. aureus bacteremia (243-249). Only two anti-S. aureus vaccines have progressed to disappointing Phase III clinical trials and those that have completed Phase II have not suggested signs of efficacy to date. All have aimed to use antibodies to mediate their effect. Production and adoptive transfer of these antibodies showed promising protection in animal challenge models in all preclinical studies. The largest clinical studies raise the possibility that colonized individuals may respond differently to vaccination.

\section{CP5 and 8 immunization}

The most prevalent $S$. aureus capsular types 5 and 8 (CP5 and 8) were conjugated to a protein carrier and this vaccine was tested in a hemodialysis population (243). Despite high antibody titers in vaccinees, a reduction in $S$. aureus bacteremia was not observed, although not all clinical isolates expressed CP. Twenty-two percentage of the participants were colonized prior to vaccination where colonization was defined as two out of two positive cultures for S. aureus from swabs of the anterior nares 2 weeks apart. Tunnel exit site colonization was not reported. They observed that while nasal carriage was a risk factor for increased bacteremia (7.6 vs. 3.1 per 100-person-years; $p<0.01$ ) among placebo recipients as expected, in vaccine recipients, the rate of $S$. aureus bacteremia among carriers was not higher than that of the non-carriers (3.0 vs. 3.1 per 100 -person-years; $p=0.82$ ). Although the numbers who developed invasive disease were small, it is an interesting observation suggesting that nasal carriage may induce a different response to vaccination. 
A smaller study of the same vaccine in healthy volunteers looked specifically at its impact on colonization (250). All had comparable antibody response post-vaccination, regardless of prior colonization status, but nasal colonization rates were not significantly affected.

\section{IsdB immunization}

In a murine model, immunization with the highly conserved iron-scavenging protein IsdB showed decreased mortality in a subsequent intravenous challenge with live $S$. aureus and seemed to correlate with anti-IsdB antibody titers (251). It was also shown to confer T cell-mediated protection by expanding a Th17 antigenspecific population, and adoptive transfer of these antigen-specific $\mathrm{CD}^{+}$cells conferred protection (203). This dual activation of humoral and cellular immunity in animal models, as well as the antigen's specificity for and conservation across $S$. aureus strains, made IsdB a highly attractive molecule for vaccination. Healthy humans have baseline anti-IsdB antibodies - presumably due to prior exposure and colonization - and titers have been shown to increase significantly between acute and convalescent samples in patients with $S$. aureus bacteremia as compared to patients with alternative infections, suggesting this response may play a role in recovery (252).

Phase IIa studies were carried out in chronic hemodialysis patients, and produced increased antibody responses in vaccinees, and increased opsonophagocytic functional activity in a subset (253). Despite the fact that $35-84 \%$ of these patients tend to be colonized with $S$. aureus, carriage rate was not reported, although prior exposure was suggested as an explanation for the brisk response and higher antibody titers seen following vaccination as compared to healthy volunteers (12). In Phase III precardiothoracic surgery patients, vaccination produced increased anti-IsdB titers, but failed to significantly reduce the incidence of S. aureus bacteremia, deep sternal wound infections, or all-cause mortality (249). However, the trial was terminated early due to increased mortality among vaccine recipients who developed $S$. aureus infection vs. placebo recipients who did, especially among those with MRSA disease. Nasal colonization rates were similar between vaccine and placebo groups, although criteria used to define this were not shown. As would be expected, invasive disease was higher among carriers than non-carriers, although these groups seemed to respond differently, just as with the CP5 and 8 vaccine trial. Vaccine efficacy appeared slightly greater in the vaccinated carrier group in post hoc analysis - invasive disease incidence was $3.3 \%$ in vaccinated carriers vs. $5.5 \%$ in placebo carriers $(p=0.09)$.

\section{DEFINING THE PURPOSE OF AN ANTI-S. AUREUS VACCINE}

A candidate vaccine must have a clearly defined purpose (Figure 3). Should a vaccine aim to prevent colonization? To prevent invasion? To augment the immune response to invasion and thus attenuate severity of disease? Should it target high-risk patient groups or be universal? Should children or infants be targeted for vaccination as their higher carriage rates make them greater potential reservoirs for transmission? What antigens, route of delivery, or adjuvant should be used? What collateral effects can be expected? Could there be a herd immunity effect? Might there

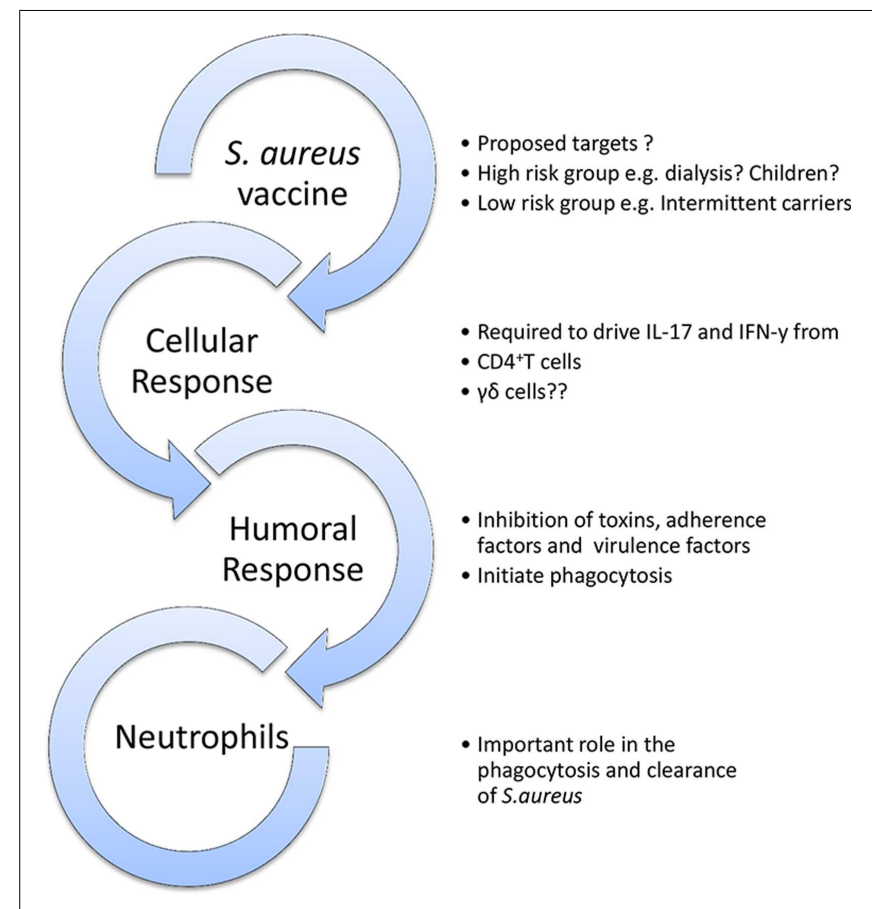

FIGURE 3 | Outline model of a protective vaccine against $\boldsymbol{S}$. aureus infection. A vaccine may be universal or specifically target high-risk groups. It should ideally aim to elicit humoral, cellular, and phagocytic responses.

be unexpected and perhaps harmful alterations in the balance of the local microbiota?

\section{THE POTENTIAL IMPACT OF S. AUREUS VACCINES ON NASAL COLONIZATION}

Unlike S. aureus, many other nasopharyngeal pathobionts have well-characterized disease-causing serotypes, or they mediate their disease by secreting local toxins rather than systemic invasion. Several also have known mechanisms of bacterial clearance (e.g., opsonizing antibodies to facilitate phagocytosis) and an established protective immunity effect whereby natural infection prevents against repeat episodes of disease. For S. aureus, none of these is known. As such, the development of a vaccine is significantly more challenging.

Since the introduction of widespread childhood vaccination, nasopharyngeal colonization rates have dropped for Corynebacterium diphtheriae, $H$. influenzae capsular type b (Hib), and vaccine serotypes of S. pneumoniae (254-256). This is in spite of the fact that many of their vaccines have specifically "anti-disease" effects and may not have been expected to influence carriage, other than reducing the efficient bacterial spread by those with disease.

The status of $S$. aureus as a harmless commensal organism in a significant proportion of the population complicates vaccine design. Colonization is the greatest risk factor for disease, yet the vast majority of carriers will never develop invasive disease. Importantly, no evolutionary or other advantage has been conclusively observed among persistent carriers of S. aureus, and conversely, no convincing disadvantage observed among those who seem resistant to colonization. Defining the differences between carrier and 
non-carrier groups has proved difficult. They are most likely multifactorial - differences in host genetics and epithelial cell molecules, differences in co-existing microbiome, and perhaps differences in $S$. aureus that make some strains superior colonizers. Difficulties in establishing clear differences between colonizing and diseasecausing strains would suggest that vaccine candidates effective at producing protection against $S$. aureus infection may also protect against colonization as an unintended collateral effect. If so, absence of $S$. aureus may alter the normal balance of the nasal microecology with potentially unpredictable results. Overgrowth of competing pathobionts could result in their causing invasive disease, or as yet unknown favorable effects of $S$. aureus on local and systemic immunity could be lost.

\section{CONSIDERING MORE THAN ANTIBODY RESPONSE IN VACCINE DESIGN}

Inducing humoral immunity would seem the most logical place to start, given its success in vaccines against S. pneumoniae, $N$. meningitidis, and $H$. influenzae. In comparison to adaptive cellular responses, antibody responses are easier to measure, and depend only on the conserved tertiary structure of a protein or polysaccharide, rather than the unknown peptide conformation of an antigen after HLA-restricted processing and presentation by APCs. However, despite multiple target antigens successfully inducing antibodies, this approach alone has not been successful. This is perhaps not surprising in light of mounting evidence that $S$. aureus has a significant propensity to "hide" intracellularly, and antibodies target extracellular pathogens (257). Additionally, the presence of staphylococcal protein A on the cell wall is a crafty anti-humoral defense mechanism, enabling the organism to immobilize antibodies on its surface and thus render them ineffective. Most importantly, clinical evidence that antibodies are important mediators of protective immunity is completely lacking, whereas cellular immune response seems to have a role in determining response to infection and perhaps colonization. It may also be likely that specific cell subsets are involved in protection against disease only in certain sites - for instance, Th17 cells appear relevant in skin and mucosal disease but are not convincingly important once systemic invasion has occurred (199, 202, 258). As such, numerous mechanisms to ensure multi-site immunity should be employed. It is now widely accepted that anti-S. aureus vaccine strategies may need to drive both humoral and cellular immune responses to confer efficient protection, and will probably require multivalent antigens and perhaps a prime-boost approach.

\section{THE LACK OF AN ANALOGOUS ANIMAL MODEL FOR CHALLENGE STUDIES IS PROBLEMATIC}

A concerning issue is the use of experimental animals who are not natural hosts for $S$. aureus in research for future vaccines. Studying candidate vaccines in rodent models has inherent limitations due to well-known differences in anatomy and immunobiology (259). Vaccine strategies shown to induce both cellular and humoral immune responses in rodents may not protect even these animals in challenge studies (260). There currently is no model truly analogous to humans to test the influence of natural and dynamic colonization on potential vaccines $(261,262)$.

Many animal studies define the efficacy of their interventions as a reduction in quantitative bacteremia or organ bacterial load, rather than sterile protection against infection. In humans, however, a threshold of "tolerable" or "safe" S. aureus bacteremia has not been found. Even endovascular infections have bacterial loads $<1000 \mathrm{CFU} / \mathrm{mL}$ in humans, and the reduction in organ bacterial loads reported as success in vaccinated animal studies may be completely irrelevant for human infections (263-265). Rather, the presence of $S$. aureus in a blood culture at any level is always considered clinically significant (266). Perhaps unsurprisingly, many interventions shown to reduce staphylococcal sepsis in animal models of systemic disease have repeatedly failed to translate into a clinical effect in humans.

Regardless of their colonization status at the time of enrollment in a clinical study - unlike their laboratory animal counterparts human participants are certainly not immunologically naïve to $S$. aureus. Initial exposure may prime the immune system and alter its response to subsequent bacterial encounters. Repeat antigen exposure may polarize and drive different cellular responses in humans than those we may hope for or expect from animal models. No candidate vaccines to date have been tested in challenge models in species that can be naturally colonized with $S$. aureus. A lifetime's exposure to $S$. aureus may leave a critical imprint on a person's immunological memory that affects subsequent response to vaccination.

\section{CONCLUSION}

The human immune system readily recognizes and mounts specific responses to $S$. aureus antigens in settings of transient exposures, persistent colonization, local, and systemic disease. Immunogenicity does not appear to be the problem, but producing a lasting protective immunity remains elusive. The major problem facing vaccine researchers is that correlates of immune protection in human S. aureus colonization and disease are not sufficiently understood, and whether a protective immune response can in fact be produced in humans is unknown. Thus, choosing markers to measure the efficacy of vaccines in preclinical studies is extremely challenging. It seems that gaining a true understanding of hostpathogen interactions, both in health and disease, should be an immediate focus of research.

Colonization is the greatest risk factor for infection, and may modify its outcome. As such, it is essential that its impact and relevance should be routinely assessed in future clinical studies. Exposure to $S$. aureus through colonization may have immunomodulatory effects on the cellular and/or humoral responses that could potentially influence vaccine-induced immunity, and thus different populations may produce different responses. Outcomes measured should routinely extend beyond antibody titers - which are of questionable significance - and include changes in the frequencies or phenotypic response of specific $\mathrm{T}$ lymphocyte populations.

It seems foolhardy to ignore the immunological memory created by colonization in trials that aim to assess the immunological effects of candidate anti-S. aureus vaccines in specific populations. It is completely unknown whether suppression or enhancement of particular cellular responses during human colonization and disease has any effect on the prevention or clearance of invasive infection. Until we understand how nasal colonization impacts host immune response, we will continue to immunize in the dark. 


\section{AUTHOR CONTRIBUTIONS}

Aisling F. Brown and John M. Leech drafted the manuscript. Thomas R. Rogers reviewed the manuscript. Rachel M. McLoughlin conceived the outline and helped draft the manuscript.

\section{ACKNOWLEDGMENTS}

We would like to thank Professor Tim Foster for his helpful comments, provision of Figure 1, and reviewing the manuscript. Aisling F. Brown and John M. Leech are supported by funding from the Health Research Board (HRA_POR/2012/104).

\section{REFERENCES}

1. MacNeal WJ, Frisbee FC, McRae MA. Staphylococcemia 1931-1940. Five hundred patients. Am J Clin Pathol (1942) 12:6.

2. Melzer M, Welch C. Thirty-day mortality in UK patients with communityonset and hospital-acquired meticillin-susceptible Staphylococcus aureus bacteraemia. J Hosp Infect (2013) 84(2):143-50. doi:10.1016/j.jhin.2012.12.013

3. Que Y-A, Moreillon P. Staphylococcus aureus (including Staphylococcal Toxic Shock). In: Mandell, Douglas and Bennett's Principles and Practices of Infectious Diseases. Philadelphia: Elsevier (2010).

4. Mertz D, Frei R, Jaussi B, Tietz A, Stebler C, Fluckiger U, et al. Throat swabs are necessary to reliably detect carriers of Staphylococcus aureus. Clin Infect Dis (2007) 45:475-7. doi:10.1086/520016

5. Acton DS, Plat-Sinnige MJ, van Wamel W, de Groot N, van Belkum A. Intestinal carriage of Staphylococcus aureus: how does its frequency compare with that of nasal carriage and what is its clinical impact? Eur J Clin Microbiol Infect Dis (2009) 28:115-27. doi:10.1007/s10096-008-0602-7

6. Bourgeois-Nicolaos N, Lucet J-C, Daubié C, Benchaba F, Rajguru M, Ruimy $\mathrm{R}$, et al. Maternal vaginal colonisation by Staphylococcus aureus and newborn acquisition at delivery. Paediatr Perinat Epidemiol (2010) 24:488-91. doi:10.1111/j.1365-3016.2010.01139.x

7. Miller LG, Eells SJ, Taylor AR, David MZ, Ortiz N, Zychowski D, et al. Staphylococcus aureus colonization among household contacts of patients with skin infections: risk factors, strain discordance, and complex ecology. Clin Infect Dis (2012) 54:1523-35. doi:10.1093/cid/cis213

8. White A. Quantitative studies of nasal carriers of staphylococci among hospitalized patients. J Clin Invest (1961) 40:23-30. doi:10.1172/JCI104233

9. Nouwen JL, Ott A, Kluytmans-Vandenbergh MF, Boelens HA, Hofman A, van Belkum A, et al. Predicting the Staphylococcus aureus nasal carrier state: derivation and validation of a "culture rule". Clin Infect Dis (2004) 39:806-11. doi:10.1086/423376

10. Mermel LA, Cartony JM, Covington P, Maxey G, Morse D. Methicillin-resistant Staphylococcus aureus colonization at different body sites: a prospective, quantitative analysis. J Clin Microbiol (2011) 49:1119-21. doi:10.1128/JCM. 02601- 10

11. van Belkum A, Verkaik NJ, de Vogel CP, Boelens HA, Verveer J, Nouwen JL, et al. Reclassification of Staphylococcus aureus nasal carriage types. J Infect Dis (2009) 199:1820-6. doi:10.1086/599119

12. Kluytmans J, van Belkum A, Verbrugh H. Nasal carriage of Staphylococcus aureus: epidemiology, underlying mechanisms, and associated risks. Clin Microbiol Rev (1997) 10:505-20.

13. Peacock SJ, Justice A, Griffiths D, de Silva GD, Kantzanou MN, Crook D, et al. Determinants of acquisition and carriage of Staphylococcus aureus in infancy. J Clin Microbiol (2003) 41:5718-25. doi:10.1128/JCM.41.12.5718-5725.2003

14. Miller LG, Diep BA. Clinical practice: colonization, fomites, and virulence: rethinking the pathogenesis of community-associated methicillin-resistant Staphylococcus aureus infection. Clin Infect Dis (2008) 46:752-60. doi:10.1086/ 526773

15. Davis MF, Iverson SA, Baron P, Vasse A, Silbergeld EK, Lautenbach E, et al. Household transmission of meticillin-resistant Staphylococcus aureus and other staphylococci. Lancet Infect Dis (2012) 12:703-16. doi:10.1016/S14733099(12)70156-1

16. Chen CS, Chen CY, Huang YC. Nasal carriage rate and molecular epidemiology of methicillin-resistant Staphylococcus aureus among medical students at a Taiwanese University. Int J Infect Dis (2012) 16:e799-803. doi:10.1016/j.ijid. 2012.07.004
17. VandenBergh MF, Yzerman EP, van Belkum A, Boelens HA, Sijmons M, Verbrugh HA. Follow-up of Staphylococcus aureus nasal carriage after 8 years: redefining the persistent carrier state. J Clin Microbiol (1999) 37:3133-40.

18. MacKinnon MM, Allen KD. Long-term MRSA carriage in hospital patients. J Hosp Infect (2000) 46:216-21. doi:10.1053/jhin.2000.0807

19. Hamdan-Partida A, Sainz-Espuñes T, Bustos-Martínez J. Characterization and persistence of Staphylococcus aureus strains isolated from the anterior nares and throats of healthy carriers in a Mexican community. J Clin Microbiol (2010) 48:1701-5. doi:10.1128/JCM.01929-09

20. Mattner F, Biertz F, Ziesing S, Gastmeier P, Chaberny IF. Long-term persistence of MRSA in re-admitted patients. Infection (2010) 38:363-71. doi:10.1007/ s15010-010-0038-8

21. Golubchik T, Batty EM, Miller RR, Farr H, Young BC, Larner-Svensson H, et al. Within-host evolution of Staphylococcus aureus during asymptomatic carriage. PLoS One (2013) 8:e61319. doi:10.1371/journal.pone.0061319

22. Muthukrishnan G, Lamers RP, Ellis A, Paramanandam V, Persaud AB, Tafur $\mathrm{S}$, et al. Longitudinal genetic analyses of Staphylococcus aureus nasal carriage dynamics in a diverse population. BMC Infect Dis (2013) 13:221. doi:10.1186/1471-2334-13-221

23. Nouwen J, Boelens H, van Belkum A, Verbrugh H. Human factor in Staphylococcus aureus nasal carriage. Infect Immun (2004) 72:6685-8. doi:10.1128/IAI 72.11.6685-6688.2004

24. den Heijer CD, van Bijnen EM, Paget WJ, Pringle M, Goossens H, Bruggeman CA, et al. Prevalence and resistance of commensal Staphylococcus aureus, including meticillin-resistant $S$. aureus, in nine European countries: a crosssectional study. Lancet Infect Dis (2013) 13:409-15. doi:10.1016/S14733099(13)70036-7

25. van Belkum A, Melles DC, Nouwen J, van Leeuwen WB, van Wamel W, Vos $\mathrm{MC}$, et al. Co-evolutionary aspects of human colonisation and infection by Staphylococcus aureus. Infect Genet Evol (2009) 9:32-47. doi:10.1016/j.meegid. 2008.09.012

26. Andersen PS, Larsen LA, Fowler VG Jr, Stegger M, Skov RL, Christensen K. Risk factors for Staphylococcus aureus nasal colonization in Danish middleaged and elderly twins. Eur J Clin Microbiol Infect Dis (2013) 32:1321-6. doi:10.1007/s10096-013-1882-0

27. Breuer K, HAussler S, Kapp A, Werfel T. Staphylococcus aureus: colonizing features and influence of an antibacterial treatment in adults with atopic dermatitis. Br J Dermatol (2002) 147:55-61. doi:10.1046/j.1365-2133.2002.04872.x

28. Laudien M, Gadola SD, Podschun R, Hedderich J, Paulsen J, ReinholdKeller E, et al. Nasal carriage of Staphylococcus aureus and endonasal activity in Wegener's granulomatosis as compared to rheumatoid arthritis and chronic rhinosinusitis with nasal polyps. Clin Exp Rheumatol (2010) 28(1 Suppl 57):51-5.

29. Bassetti S, Dunagan DP, D'Agostino RB Jr, Sherertz RJ. Nasal carriage of Staphylococcus aureus among patients receiving allergen-injection immunotherapy: associated factors and quantitative nasal cultures. Infect Control Hosp Epidemiol (2001) 22:741-5. doi:10.1086/501857

30. Weinke T, Schiller R, Fehrenbach FJ, Pohle HD. Association between Staphylococcus aureus nasopharyngeal colonization and septicemia in patients infected with the human immunodeficiency virus. Eur J Clin Microbiol Infect Dis (1992) 11:985-9. doi:10.1007/BF01967787

31. Miller M, Cespedes C, Bhat M, Vavagiakis P, Klein RS, Lowy FD. Incidence and persistence of Staphylococcus aureus nasal colonization in a community sample of HIV-infected and -uninfected drug users. Clin Infect Dis (2007) 45:343-6. doi:10.1086/519429

32. Pujol M, Pena C, Pallares R, Ariza J, Ayats J, Dominguez MA, et al. Nosocomial Staphylococcus aureus bacteremia among nasal carriers of methicillinresistant and methicillin-susceptible strains. Am J Med (1996) 100:509-16. doi:10.1016/S0002-9343(96)00014-9

33. Corbella X, Dominguez MA, Pujol M, Ayats J, Sendra M, Pallares R, et al. Staphylococcus aureus nasal carriage as a marker for subsequent staphylococcal infections in intensive care unit patients. Eur J Clin Microbiol Infect Dis (1997) 16:351-7. doi:10.1007/BF01726362

34. Jensen AG, Wachmann CH, Poulsen KB, Espersen F, Scheibel J, Skinhoj P, et al. Risk factors for hospital-acquired Staphylococcus aureus bacteremia. Arch Intern Med (1999) 159:1437-44. doi:10.1001/archinte.159.13.1437

35. Harinstein L, Schafer J, D'Amico F. Risk factors associated with the conversion of meticillin-resistant Staphylococcus aureus colonisation to 
healthcare-associated infection. J Hosp Infect (2011) 79:194-7. doi:10.1016/ j.jhin.2011.03.017

36. von Eiff C, Becker K, Machka K, Stammer H, Peters G. Nasal carriage as a source of Staphylococcus aureus bacteremia. N Engl J Med (2001) 344:11-6. doi:10.1056/NEJM200101043440102

37. Wertheim HF, Vos MC, Ott A, van Belkum A, Voss A, Kluytmans JA, et al. Risk and outcome of nosocomial Staphylococcus aureus bacteraemia in nasal carriers versus non-carriers. Lancet (2004) 364:703-5. doi:10.1016/S0140-6736(04) 16897-9

38. Sewell CM, Clarridge J, Lacke C, Weinman EJ, Young EJ. Staphylococcal nasal carriage and subsequent infection in peritoneal dialysis patients. JAMA (1982) 248:1493-5. doi:10.1001/jama.248.12.1493

39. Luzar MA, Coles GA, Faller B, Slingeneyer A, Dah GD, Briat C, et al. Staphylococcus aureus nasal carriage and infection in patients on continuous ambulatory peritoneal dialysis. N Engl J Med (1990) 322:505-9. doi:10.1056/ NEJM199002223220804

40. Kluytmans JA, Mouton JW, Ijzerman EP, Vandenbroucke-Grauls CM, Maat AW, Wagenvoort JH, et al. Nasal carriage of Staphylococcus aureus as a major risk factor for wound infections after cardiac surgery. J Infect Dis (1995) 171:216-9. doi:10.1093/infdis/171.1.216

41. Kluytmans JA, Wertheim HF. Nasal carriage of Staphylococcus aureus and prevention of nosocomial infections. Infection (2005) 33:3-8. doi:10.1007/s15010005-4012-9

42. Nouwen JL, Fieren MW, Snijders S, Verbrugh HA, van Belkum A. Persistent (not intermittent) nasal carriage of Staphylococcus aureus is the determinant of CPD-related infections. Kidney Int (2005) 67:1084-92. doi:10.1111/j.15231755.2005.00174.x

43. Tulloch LG. Nasal carriage in staphylococcal skin infections. Br Med J (1954) 2:912-3. doi:10.1136/bmj.2.4893.912

44. Safdar N, Bradley EA. The risk of infection after nasal colonization with Staphylococcus aureus. Am J Med (2008) 121:310-5. doi:10.1016/j.amjmed.2007.07. 034

45. Honda H, Krauss MJ, Coopersmith CM, Kollef MH, Richmond AM, Fraser VJ, et al. Staphylococcus aureus nasal colonization and subsequent infection in intensive care unit patients: does methicillin resistance matter? Infect Control Hosp Epidemiol (2010) 31:584-91. doi:10.1086/652530

46. Ellis MW, Hospenthal DR, Dooley DP, Gray PJ, Murray CK. Natural history of community-acquired methicillin-resistant Staphylococcus aureus colonization and infection in soldiers. Clin Infect Dis (2004) 39:971-9. doi:10.1086/423965

47. Kazakova SV, Hageman JC, Matava M, Srinivasan A, Phelan L, Garfinkel B, et al. A clone of methicillin-resistant Staphylococcus aureus among professional football players. N Engl J Med (2005) 352:468-75. doi:10.1056/NEJMoa042859

48. Deleo FR, Otto M, Kreiswirth BN, Chambers HF. Community-associated meticillin-resistant Staphylococcus aureus. Lancet (2010) 375:1557-68. doi:10. 1016/S0140-6736(09)61999-1

49. Eells SJ, McKinnell JA, Wang AA, Green NL, Whang D, O'Hara P, et al. A comparison of clinical outcomes between healthcare-associated infections due to community-associated methicillin-resistant Staphylococcus aureus strains and healthcare-associated methicillin-resistant S. aureus strains. Epidemiol Infect (2013) 141:2140-8. doi:10.1017/S0950268812002634

50. Nubel U, Roumagnac P, Feldkamp M, Song JH, Ko KS, Huang YC, et al. Frequent emergence and limited geographic dispersal of methicillin-resistant Staphylococcus aureus. Proc Natl Acad Sci U S A (2008) 105:14130-5. doi:10. 1073/pnas.0804178105

51. Freitas EA, Harris RM, Blake RK, Salgado CD. Prevalence of USA300 strain type of methicillin-resistant Staphylococcus aureus among patients with nasal colonization identified with active surveillance. Infect Control Hosp Epidemiol (2010) 31:469-75. doi:10.1086/651672

52. Monecke S, Coombs G, Shore AC, Coleman DC, Akpaka P, Borg M, et al. A field guide to pandemic, epidemic and sporadic clones of methicillin-resistant Staphylococcus aureus. PLoS One (2011) 6:e17936. doi:10.1371/journal.pone. 0017936

53. Rolo J, Miragaia M, Turlej-Rogacka A, Empel J, Bouchami O, Faria NA, et al. High genetic diversity among community-associated Staphylococcus aureus in Europe: results from a multicenter study. PLoS One (2012) 7:e34768. doi:10.1371/journal.pone. 0034768

54. Laupland KB, Ross T, Gregson DB. Staphylococcus aureus bloodstream infections: risk factors, outcomes, and the influence of methicillin resistance in Calgary, Canada, 2000-2006. J Infect Dis (2008) 198:336-43. doi:10.1086/ 589717

55. Ten Broeke-Smits NJ, Kummer JA, Bleys RL, Fluit AC, Boel CH. Hair follicles as a niche of Staphylococcus aureus in the nose; is a more effective decolonisation strategy needed? J Hosp Infect (2010) 76:211-4. doi:10.1016/j.jhin.2010.07.011

56. Aly R, Shinefield HI, Strauss WG, Maibach HI. Bacterial adherence to nasal mucosal cells. Infect Immun (1977) 17:546-9.

57. Pynnonen M, Stephenson RE, Schwartz K, Hernandez M, Boles BR. Hemoglobin promotes Staphylococcus aureus nasal colonization. PLoS Pathog (2011) 7:e1002104. doi:10.1371/journal.ppat.1002104

58. Burian M, Wolz C, Goerke C. Regulatory adaptation of Staphylococcus aureus during nasal colonization of humans. PLoS One (2010) 5:e10040. doi:10.1371/ journal.pone. 0010040

59. Muthukrishnan G, Quinn GA, Lamers RP, Diaz C, Cole AL, Chen S, et al. Exoproteome of Staphylococcus aureus reveals putative determinants of nasal carriage. J Proteome Res (2011) 10:2064-78. doi:10.1021/pr200029r

60. Wertheim HF, Walsh E, Choudhurry R, Melles DC, Boelens HA, Miajlovic H, et al. Key role for clumping factor B in Staphylococcus aureus nasal colonization of humans. PLoS Med (2008) 5:e17. doi:10.1371/journal.pmed.0050017

61. Mulcahy ME, Geoghegan JA, Monk IR, O'Keeffe KM, Walsh EJ, Foster TJ, et al. Nasal colonisation by Staphylococcus aureus depends upon clumping factor B binding to the squamous epithelial cell envelope protein loricrin. PLoS Pathog (2012) 8:e1003092. doi:10.1371/journal.ppat.1003092

62. Koch PJ, de Viragh PA, Scharer E, Bundman D, Longley MA, Bickenbach J, et al. Lessons from loricrin-deficient mice: compensatory mechanisms maintaining skin barrier function in the absence of a major cornified envelope protein. JCell Biol (2000) 151:389-400. doi:10.1083/jcb.151.2.389

63. O’Driscoll J, Muston GC, McGrath JA, Lam HM, Ashworth J, Christiano AM. A recurrent mutation in the loricrin gene underlies the ichthyotic variant of Vohwinkel syndrome. Clin Exp Dermatol (2002) 27:243-6. doi:10.1046/j.13652230.2002.01031.x

64. Clarke SR, Brummell KJ, Horsburgh MJ, McDowell PW, Mohamad SA, Stapleton MR, et al. Identification of in vivo-expressed antigens of Staphylococcus aureus and their use in vaccinations for protection against nasal carriage. J Infect Dis (2006) 193:1098-108. doi:10.1086/501471

65. Clarke SR, Andre G, Walsh EJ, Dufrene YF, Foster TJ, Foster SJ. Iron-regulated surface determinant protein A mediates adhesion of Staphlococcus aureus to human corneocyte envelope proteins. Infect Immun (2009) 77:2408-16. doi:10.1128/IAI.01304-08

66. Corrigan RM, Miajlovic H, Foster TJ. Surface proteins that promote adherence of Staphylococcus aureus to human desquamated nasal epithelial cells. BMC Microbiol (2009) 9:22. doi:10.1186/1471-2180-9-22

67. Schauber J, Gallo RL. Antimicrobial peptides and the skin immune defense system. J Allergy Clin Immunol (2009) 124:R13-8. doi:10.1016/j.jaci.2009.07.014

68. Hancock RE, Sahl HG. Antimicrobial and host-defense peptides as new antiinfective therapeutic strategies. Nat Biotechnol (2006) 24:1551-7. doi:10.1038/ nbt1267

69. van Belkum A, Emonts M, Wertheim H, de Jongh C, Nouwen J, Bartels H, et al. The role of human innate immune factors in nasal colonization by Staphylococcus aureus. Microbes Infect (2007) 9:1471-7. doi:10.1016/j.micinf.2007.08.003

70. Cole AM, Tahk S, Oren A, Yoshioka D, Kim YH, Park A, et al. Determinants of Staphylococcus aureus nasal carriage. Clin Diagn Lab Immunol (2001) 8(6):1064-9.

71. Midorikawa K, Ouhara K, Komatsuzawa H, Kawai T, Yamada S, Fujiwara T, et al. Staphylococcus aureus susceptibility to innate antimicrobial peptides, betadefensins and CAP18, expressed by human keratinocytes. Infect Immun (2003) 71:3730-9. doi:10.1128/IAI.71.7.3730-3739.2003

72. Kisich KO, Howell MD, Boguniewicz M, Heizer HR, Watson NU, Leung DY. The constitutive capacity of human keratinocytes to kill Staphylococcus aureus is dependent on beta-defensin 3. J Invest Dermatol (2007) 127:2368-80. doi:10.1038/sj.jid.5700861

73. Zanger P, Holzer J, Schleucher R, Scherbaum H, Schittek B, Gabrysch S. Severity of Staphylococcus aureus infection of the skin is associated with inducibility of human beta-defensin 3 but not human beta-defensin 2. Infect Immun (2010) 78:3112-7. doi:10.1128/IAI.00078-10

74. Menzies BE, Kenoyer A. Staphylococcus aureus infection of epidermal keratinocytes promotes expression of innate antimicrobial peptides. Infect Immun (2005) 73:5241-4. doi:10.1128/IAI.73.8.5241-5244.2005 
75. Hui Y, Wohlers J, Podschun R, Hedderich J, Lamprecht P, Ambrosch P, et al. Antimicrobial peptides in nasal secretion and mucosa with respect to $S$. aureus colonisation in Wegener's granulomatosis. Clin Exp Rheumatol (2011) 29(1 Suppl 64):S49-56.

76. Zanger P, Nurjadi D, Vath B, Kremsner PG. Persistent nasal carriage of Staphylococcus aureus is associated with deficient induction of human beta-defensin 3 after sterile wounding of healthy skin in vivo. Infect Immun (2011) 79:2658-62. doi:10.1128/IAI.00101-11

77. Nurjadi D, Herrmann E, Hinderberger I, Zanger P. Impaired beta-defensin expression in human skin links DEFB1 promoter polymorphisms with persistent Staphylococcus aureus nasal carriage. J Infect Dis (2013) 207:666-74. doi:10.1093/infdis/jis735

78. Yamasaki K, Gallo RL. Antimicrobial peptides in human skin disease. Eur J Dermatol (2008) 18(1):11-21.

79. Noore J, Noore A, Li B. Cationic antimicrobial peptide LL-37 is effective against both extra- and intracellular Staphylococcus aureus. Antimicrob Agents Chemother (2013) 57:1283-90. doi:10.1128/AAC.01650-12

80. Schauber J, Oda Y, Buchau AS, Yun QC, Steinmeyer A, Zugel U, et al. Histone acetylation in keratinocytes enables control of the expression of cathelicidin and CD14 by 1,25-dihydroxyvitamin D3. J Invest Dermatol (2008) 128:816-24. doi:10.1038/sj.jid.5701102

81. Roider E, Ruzicka T, Schauber J. Vitamin d, the cutaneous barrier, antimicrobial peptides and allergies: is there a link? Allergy Asthma Immunol Res (2013) 5:119-28. doi:10.4168/aair.2013.5.3.119

82. Matheson EM, Mainous AG III, Hueston WJ, Diaz VA, Everett CJ. Vitamin D and methicillin-resistant Staphylococcus aureus nasal carriage. Scand J Infect Dis (2010) 42:455-60. doi:10.3109/00365541003602049

83. Olsen K, Falch BM, Danielsen K, Johannessen M, Ericson Sollid JU, Thune I, et al. Staphylococcus aureus nasal carriage is associated with serum 25hydroxyvitamin D levels, gender and smoking status. The Tromso Staph and Skin Study. Eur J Clin Microbiol Infect Dis (2012) 31:465-73. doi:10.1007/ s10096-011-1331-x

84. Slow S, Priest PC, Chambers ST, Stewart AW, Jennings LC, Florkowski CM, et al Effect of vitamin D3 supplementation on Staphylococcus aureus nasal carriage: a randomized, double-blind, placebo-controlled trial in healthy adults. Clin Microbiol Infect (2013). doi:10.1111/1469-0691.12350

85. Proksch E, Brandner JM, Jensen JM. The skin: an indispensable barrier. Exp Dermatol (2008) 17:1063-72. doi:10.1111/j.1600-0625.2008.00786.x

86. Lee JT, Jansen M, Yilma AN, Nguyen A, Desharnais R, Porter E. Antimicrobial lipids: novel innate defense molecules are elevated in sinus secretions of patients with chronic rhinosinusitis. Am J Rhinol Allergy (2010) 24:99-104. doi:10.2500/ajra.2010.24.3444

87. Chen CH, Wang Y, Nakatsuji T, Liu YT, Zouboulis C, Gallo R, et al. An innate bactericidal oleic acid effective against skin infection of methicillinresistant Staphylococcus aureus: a therapy concordant with evolutionary medicine. J Microbiol Biotechnol (2011) 21(4):391-9.

88. Huang CM, Chen CH, Pornpattananangkul D, Zhang L, Chan M, Hsieh MF, et al. Eradication of drug resistant Staphylococcus aureus by liposomal oleic acids. Biomaterials (2011) 32:214-21. doi:10.1016/j.biomaterials.2010.08.076

89. Johannessen M, Sollid JE, Hanssen AM. Host- and microbe determinants that may influence the success of S. aureus colonization. Front Cell Infect Microbiol (2012) 2:56. doi:10.3389/fcimb.2012.00056

90. Miajlovic H, Fallon PG, Irvine AD, Foster TJ. Effect of filaggrin breakdown products on growth of and protein expression by Staphylococcus aureus. J Allergy Clin Immunol (2010) 126(1184-1190):e1183. doi:10.1016/j.jaci.2010. 09.015

91. Arikawa J, Ishibashi M, Kawashima M, Takagi Y, Ichikawa Y, Imokawa G. Decreased levels of sphingosine, a natural antimicrobial agent, may be associated with vulnerability of the stratum corneum from patients with atopic dermatitis to colonization by Staphylococcus aureus. J Invest Dermatol (2002) 119:433-9. doi:10.1046/j.1523-1747.2002.01846.x

92. Takigawa H, Nakagawa H, Kuzukawa M, Mori H, Imokawa G. Deficient production of hexadecenoic acid in the skin is associated in part with the vulnerability of atopic dermatitis patients to colonization by Staphylococcus aureus. Dermatology (2005) 211:240-8. doi:10.1159/000087018

93. Wohlers J, Breucker K, Podschun R, Hedderich J, Lamprecht P, Ambrosch P, et al. Aberrant cytokine pattern of the nasal mucosa in granulomatosis with polyangiitis. Arthritis Res Ther (2012) 14:R203. doi:10.1186/ar4041
94. Rieg S, Kaasch AJ, Wehrle J, Hofmann SC, Szymaniak-Vits M, Saborowski V, et al. Susceptibility of clinical Staphylococcus aureus isolates to innate defense antimicrobial peptides. Microbes Infect (2011) 13:761-5. doi:10.1016/j.micinf. 2011.03.010

95. Kinsman OS, McKenna R, Noble WC. Association between histocompatability antigens (HLA) and nasal carriage of Staphylococcus aureus. J Med Microbiol (1983) 16:215-20. doi:10.1099/00222615-16-2-215

96. Ruimy R, Angebault C, Djossou F, Dupont C, Epelboin L, Jarraud S, et al. Are host genetics the predominant determinant of persistent nasal Staphylococcus aureus carriage in humans? J Infect Dis (2010) 202:924-34. doi:10.1086/655901

97. Vuononvirta J, Toivonen L, Grondahl-Yli-Hannuksela K, Barkoff AM, Lindholm L, Mertsola J, et al. Nasopharyngeal bacterial colonization and gene polymorphisms of mannose-binding lectin and toll-like receptors 2 and 4 in infants. PLoS One (2011) 6:e26198. doi:10.1371/journal.pone.0026198

98. Sasaki S, Nishikawa S, Miura T, Mizuki M, Yamada K, Madarame H, et al. Interleukin-4 and interleukin-10 are involved in host resistance to Staphylococcus aureus infection through regulation of gamma interferon. Infect Immun (2000) 68:2424-30. doi:10.1128/IAI.68.5.2424-2430.2000

99. Emonts M, Uitterlinden AG, Nouwen JL, Kardys I, Maat MP, Melles DC, et al. Host polymorphisms in interleukin 4, complement factor $\mathrm{H}$, and C-reactive protein associated with nasal carriage of Staphylococcus aureus and occurrence of boils. J Infect Dis (2008) 197:1244-53. doi:10.1086/533501

100. van den Akker EL, Nouwen JL, Melles DC, van Rossum EF, Koper JW, Uitterlinden AG, et al. Staphylococcus aureus nasal carriage is associated with glucocorticoid receptor gene polymorphisms. J Infect Dis (2006) 194:814-8. doi: $10.1086 / 506367$

101. Roghmann MC, Johnson JK, Stine OC, Lydecker AD, Ryan KA, Mitchell BD, et al. Persistent Staphylococcus aureus colonization is not a strongly heritable trait in Amish families. PLoS One (2011) 6:e17368. doi:10.1371/journal.pone. 0017368

102. Andersen PS, Pedersen JK, Fode P, Skov RL, Fowler VG Jr, Stegger M, et al. Influence of host genetics and environment on nasal carriage of staphylococcus aureus in Danish middle-aged and elderly twins. J Infect Dis (2012) 206:1178-84. doi:10.1093/infdis/jis491

103. Cui L, Morris A, Ghedin E. The human mycobiome in health and disease. Genome Med (2013) 5:63. doi:10.1186/gm467

104. Duerkop BA, Hooper LV. Resident viruses and their interactions with the immune system. Nat Immunol (2013) 14:654-9. doi:10.1038/ni.2614

105. Huffnagle GB, Noverr MC. The emerging world of the fungal microbiome. Trends Microbiol (2013) 21:334-41. doi:10.1016/j.tim.2013.04.002

106. Spuesens EB, Fraaij PL, Visser EG, Hoogenboezem T, Hop WC, van Adrichem $\mathrm{LN}$, et al. Carriage of Mycoplasma pneumoniae in the upper respiratory tract of symptomatic and asymptomatic children: an observational study. PLoS Med (2013) 10:e1001444. doi:10.1371/journal.pmed.1001444

107. Frank DN, Feazel LM, Bessesen MT, Price CS, Janoff EN, Pace NR. The human nasal microbiota and Staphylococcus aureus carriage. PLoS One (2010) 5:e10598. doi:10.1371/journal.pone.0010598

108. Human Microbiome Project Consortium. Structure, function and diversity of the healthy human microbiome. Nature (2012) 486:207-14. doi:10.1038/ nature 11234

109. Dall'Antonia M, Coen PG, Wilks M, Whiley A, Millar M. Competition between methicillin-sensitive and -resistant Staphylococcus aureus in the anterior nares. J Hosp Infect (2005) 61:62-7. doi:10.1016/j.jhin.2005.01.008

110. Margolis E, Yates A, Levin BR. The ecology of nasal colonization of Streptococcus pneumoniae, Haemophilus influenzae and Staphylococcus aureus: the role of competition and interactions with host's immune response. BMC Microbiol (2010) 10:59. doi:10.1186/1471-2180-10-59

111. Cespedes C, Said-Salim B, Miller M, Lo SH, Kreiswirth BN, Gordon RJ, et al. The clonality of Staphylococcus aureus nasal carriage. J Infect Dis (2005) 191:444-52. doi:10.1086/427240

112. Kildow BJ, Conradie JP, Robson RL. Nostrils of healthy volunteers are independent with regard to Staphylococcus aureus carriage. J Clin Microbiol (2012) 50:3744-6. doi:10.1128/JCM.01488-12

113. Van Eldere J, Peetermans WE, Struelens M, Deplano A, Bobbaers H. Polyclonal Staphylococcal endocarditis caused by genetic variability. Clin Infect Dis (2000) 31:24-30. doi:10.1086/313915

114. Ji G, Beavis R, Novick RP. Bacterial interference caused by autoinducing peptide variants. Science (1997) 276:2027-30. doi:10.1126/science.276.5321.2027 
115. Park B, Iwase T, Liu GY. Intranasal application of S. epidermidis prevents colonization by methicillin-resistant Staphylococcus aureus in mice. PLoS One (2011) 6:e25880. doi:10.1371/journal.pone.0025880

116. Iwase T, Uehara Y, Shinji H, Tajima A, Seo H, Takada K, et al. Staphylococcus epidermidis Esp inhibits Staphylococcus aureus biofilm formation and nasal colonization. Nature (2010) 465:346-9. doi:10.1038/nature09074

117. Shinefield HR, Ribble JC, Boris M, Eichenwald HF, Aly R, Maibach H. Bacterial interference between strains of S. aureus. Ann N Y Acad Sci (1974) 236:444-55. doi:10.1111/j.1749-6632.1974.tb41509.x

118. St Sauver J, Marrs CF, Foxman B, Somsel P, Madera R, Gilsdorf JR. Risk factors for otitis media and carriage of multiple strains of Haemophilus influenzae and Streptococcus pneumoniae. Emerg Infect Dis (2000) 6:622-30. doi:10.3201/eid0606.000611

119. Bogaert D, van Belkum A, Sluijter M, Luijendijk A, de Groot R, Rumke HC, et al. Colonisation by Streptococcus pneumoniae and Staphylococcus aureus in healthy children. Lancet (2004) 363:1871-2. doi:10.1016/S0140-6736(04)16357-5

120. McNally LM, Jeena PM, Gajee K, Sturm AW, Tomkins AM, Coovadia HM, et al. Lack of association between the nasopharyngeal carriage of Streptococcus pneumoniae and Staphylococcus aureus in HIV-1-infected South African children. J Infect Dis (2006) 194:385-90. doi:10.1086/505076

121. Jourdain S, Smeesters PR, Denis O, Dramaix M, Sputael V, Malaviolle X, et al. Differences in nasopharyngeal bacterial carriage in preschool children from different socio-economic origins. Clin Microbiol Infect (2011) 17:907-14. doi:10.1111/j.1469-0691.2010.03410.x

122. Selva L, Viana D, Regev-Yochay G, Trzcinski K, Corpa JM, Lasa I, et al. Killing niche competitors by remote-control bacteriophage induction. Proc Natl Acad Sci U S A (2009) 106:1234-8. doi:10.1073/pnas.0809600106

123. Aly R, Maibach HI, Strauss WG, Shinefield HR. Effects of a systemic antibiotic on nasal bacterial ecology in man. Appl Microbiol (1970) 20:240-4.

124. van Rijen M, Bonten M, Wenzel R, Kluytmans J. Mupirocin ointment for preventing Staphylococcus aureus infections in nasal carriers. Cochrane Database Syst Rev (2008) 4:CD006216. doi:10.1002/14651858.CD006216.pub2

125. Simor AE. Staphylococcal decolonisation: an effective strategy for prevention of infection? Lancet Infect Dis (2011) 11:952-62. doi:10.1016/S1473-3099(11) 70281-X

126. Uehara Y, Nakama H, Agematsu K, Uchida M, Kawakami Y, Abdul Fattah AS, et al. Bacterial interference among nasal inhabitants: eradication of Staphylococcus aureus from nasal cavities by artificial implantation of Corynebacterium sp. J Hosp Infect (2000) 44:127-33. doi:10.1053/jhin.1999.0680

127. Glück U, Gebbers JO. Ingested probiotics reduce nasal colonization with pathogenic bacteria (Staphylococcus aureus, Streptococcus pneumoniae, and betahemolytic streptococci). Am J Clin Nutr (2003) 77(2):517-20.

128. Carlson E. Enhancement by Candida albicans of Staphylococcus aureus, Serratia marcescens, and Streptococcus faecalis in the establishment of infection in mice. Infect Immun (1983) 39:193-7.

129. Peters BM, Noverr MC. Candida albicans-Staphylococcus aureus polymicrobial peritonitis modulates host innate immunity. Infect Immun (2013) 81:2178-89. doi:10.1128/IAI.00265-13

130. Jabra-Rizk MA, Meiller TF, James CE, Shirtliff ME. Effect of farnesol on Staphylococcus aureus biofilm formation and antimicrobial susceptibility. Antimicrob Agents Chemother (2006) 50:1463-9. doi:10.1128/AAC.50.4.1463-1469.2006

131. Smith K, McCoy KD, Macpherson AJ. Use of axenic animals in studying the adaptation of mammals to their commensal intestinal microbiota. Semin Immunol (2007) 19:59-69. doi:10.1016/j.smim.2006.10.002

132. Round JL, Mazmanian SK. The gut microbiota shapes intestinal immune responses during health and disease. Nat Rev Immunol (2009) 9:313-23. doi:10.1038/nri2515

133. Sommer F, Backhed F. The gut microbiota - masters of host development and physiology. Nat Rev Microbiol (2013) 11:227-38. doi:10.1038/nrmicro2974

134. Geuking MB, Cahenzli J, Lawson MA, Ng DC, Slack E, Hapfelmeier S, et al. Intestinal bacterial colonization induces mutualistic regulatory $\mathrm{T}$ cell responses. Immunity (2011) 34:794-806. doi:10.1016/j.immuni.2011.03.021

135. Powrie F, Leach MW, Mauze S, Caddle LB, Coffman RL. Phenotypically distinct subsets of CD4+ $\mathrm{T}$ cells induce or protect from chronic intestinal inflammation in C. B-17 scid mice. Int Immunol (1993) 5:1461-71. doi:10.1093/intimm/5.11.1461
136. Kamada N, Seo SU, Chen GY, Nunez G. Role of the gut microbiota in immunity and inflammatory disease. Nat Rev Immunol (2013) 13:321-35. doi:10.1038/nri3430

137. Naik S, Bouladoux N, Wilhelm C, Molloy MJ, Salcedo R, Kastenmuller W, et al. Compartmentalized control of skin immunity by resident commensals. Science (2012) 337:1115-9. doi:10.1126/science.1225152

138. de Roock S, van Elk M, van Dijk ME, Timmerman HM, Rijkers GT, Prakken BJ, et al. Lactic acid bacteria differ in their ability to induce functional regulatory $\mathrm{T}$ cells in humans. Clin Exp Allergy (2010) 40:103-10. doi:10.1111/j.1365-2222. 2009.03344.x

139. Noverr MC, Phare SM, Toews GB, Coffey MJ, Huffnagle GB. Pathogenic yeasts Cryptococcus neoformans and Candida albicans produce immunomodulatory prostaglandins. Infect Immun (2001) 69:2957-63. doi:10.1128/IAI.69.5.29572963.2001

140. Bach JF. Protective role of infections and vaccinations on autoimmune diseases. J Autoimmun (2001) 16:347-53. doi:10.1006/jaut.2000.0478

141. Bjorksten B. Diverse microbial exposure - consequences for vaccine development. Vaccine (2012) 30:4336-40. doi:10.1016/j.vaccine.2011.10.074

142. McLoughlin RM, Calatroni A, Visness CM, Wallace PK, Cruikshank WW, Tuzova M, et al. Longitudinal relationship of early life immunomodulatory $\mathrm{T}$ cell phenotype and function to development of allergic sensitization in an urban cohort. Clin Exp Allergy (2012) 42:392-404. doi:10.1111/j.1365-2222. 2011.03882.x

143. Konrad A, Cong Y, Duck W, Borlaza R, Elson CO. Tight mucosal compartmentation of the murine immune response to antigens of the enteric microbiota. Gastroenterology (2006) 130:2050-9. doi:10.1053/j.gastro.2006.02.055

144. Gautreaux MD, Deitch EA, Berg RD. T lymphocytes in host defense against bacterial translocation from the gastrointestinal tract. Infect Immun (1994) 62:2874-84.

145. Cohen IR, Norins LC. Natural human antibodies to gram-negative bacteria: immunoglobulins G, A, and M. Science (1966) 152:1257-9.

146. Faux JA, Agbarakwe AE, Misbah SA, Chapel HM. A comparison of specific IgG antibody levels to the cell wall mannan of Candida albicans in normal individuals and in patients with primary antibody deficiency. J Immunol Methods (1992) 153:167-72. doi:10.1016/0022-1759(92)90319-O

147. Allan E, Poxton IR, Barclay GR. Anti-bacteroides lipopolysaccharide IgG levels in healthy adults and sepsis patients. FEMS Immunol Med Microbiol (1995) 11:5-12. doi:10.1111/j.1574-695X.1995.tb00072.x

148. Kyne L, Warny M, Qamar A, Kelly CP. Asymptomatic carriage of Clostridium difficile and serum levels of IgG antibody against toxin A. N Engl J Med (2000) 342:390-7. doi:10.1056/NEJM200002103420604

149. Haas A, Zimmermann K, Graw F, Slack E, Rusert P, Ledergerber B, et al. Systemic antibody responses to gut commensal bacteria during chronic HIV-1 infection. Gut (2011) 60:1506-19. doi:10.1136/gut.2010.224774

150. Currie CG, McCallum K, Poxton IR. Mucosal and systemic antibody responses to the lipopolysaccharide of Escherichia coli O157 in health and disease. J Med Microbiol (2001) 50(4):345-54.

151. Furrie E, Macfarlane S, Cummings JH, Macfarlane GT. Systemic antibodies towards mucosal bacteria in ulcerative colitis and Crohn's disease differentially activate the innate immune response. Gut (2004) 53:91-8. doi:10.1136/gut.53. 1.91

152. Sanchez-Hurtado K, Corretge M, Mutlu E, McIlhagger R, Starr JM, Poxton IR. Systemic antibody response to Clostridium difficile in colonized patients with and without symptoms and matched controls. J Med Microbiol (2008) 57:717-24. doi:10.1099/jmm.0.47713-0

153. Ergin A, Syrbe U, Scheer R, Thiel A, Adam T, Büssow K, et al. Impaired peripheral Th1 CD4+ T cell response to Escherichia coli proteins in patients with Crohn's disease and ankylosing spondylitis. J Clin Immunol (2011) 31:998-1009. doi:10.1007/s10875-011-9575-x

154. Hand TW, Dos Santos LM, Bouladoux N, Molloy MJ, Pagan AJ, Pepper M, et al. Acute gastrointestinal infection induces long-lived microbiota-specific $\mathrm{T}$ cell responses. Science (2012) 337:1553-6. doi:10.1126/science.1220961

155. Pepper M, Linehan JL, Pagan AJ, Zell T, Dileepan T, Cleary PP, et al. Different routes of bacterial infection induce long-lived TH1 memory cells and short-lived TH17 cells. Nat Immunol (2010) 11:83-9. doi:10.1038/ ni. 1826 
156. Pido-Lopez J, Kwok WW, Mitchell TJ, Heyderman RS, Williams NA. Acquisition of pneumococci specific effector and regulatory Cd4+ T cells localising within human upper respiratory-tract mucosal lymphoid tissue. PLoS Pathog (2011) 7:e1002396. doi:10.1371/journal.ppat.1002396

157. Ferreira DM, Neill DR, Bangert M, Gritzfeld JF, Green N, Wright AK, et al. Controlled human infection and rechallenge with Streptococcus pneumoniae reveals the protective efficacy of carriage in healthy adults. Am J Respir Crit Care Med (2013) 187:855-64. doi:10.1164/rccm.201212-2277OC

158. Wright AK, Bangert M, Gritzfeld JF, Ferreira DM, Jambo KC, Wright AD, et al. Experimental human pneumococcal carriage augments IL-17A-dependent T-cell defence of the lung. PLoS Pathog (2013) 9:e1003274. doi:10.1371/ journal.ppat.1003274

159. Lu YJ, Gross J, Bogaert D, Finn A, Bagrade L, Zhang Q, et al. Interleukin17A mediates acquired immunity to pneumococcal colonization. PLoS Pathog (2008) 4:e1000159. doi:10.1371/journal.ppat.1000159

160. Zhang Q, Leong SC, McNamara PS, Mubarak A, Malley R, Finn A. Characterisation of regulatory $\mathrm{T}$ cells in nasal associated lymphoid tissue in children: relationships with pneumococcal colonization. PLoS Pathog (2011) 7:e1002175. doi:10.1371/journal.ppat.1002175

161. Aslam A, Chapel H, Ogg G. Direct ex-vivo evaluation of pneumococcal specific T-cells in healthy adults. PLoS One (2011) 6:e25367. doi:10.1371/journal.pone. 0025367

162. Cohen JM, Khandavilli S, Camberlein E, Hyams C, Baxendale HE, Brown JS. Protective contributions against invasive Streptococcus pneumoniae pneumonia of antibody and Th17-cell responses to nasopharyngeal colonisation. PLoS One (2011) 6:e25558. doi:10.1371/journal.pone.0025558

163. Schweizer ML, Bossen A, McDanel JS, Dennis LK. Staphylococcus aureus colonization before infection is not associated with mortality among $S$. aureus-infected patients: a meta-analysis. Infect Control Hosp Epidemiol (2012) 33:796-802. doi:10.1086/666628

164. Stolz SJ, Davis JP, Vergeront JM, Crass BA, Chesney PJ, Wand PJ, et al. Development of serum antibody to toxic shock toxin among individuals with toxic shock syndrome in Wisconsin. J Infect Dis (1985) 151:883-9. doi:10.1093/infdis/151.5.883

165. Holtfreter S, Roschack K, Eichler P, Eske K, Holtfreter B, Kohler C, et al. Staphylococcus aureus carriers neutralize superantigens by antibodies specific for their colonizing strain: a potential explanation for their improved prognosis in severe sepsis. J Infect Dis (2006) 193:1275-8. doi:10.1086/503048

166. Adhikari RP, Ajao AO, Aman MJ, Karauzum H, Sarwar J, Lydecker AD, et al. Lower antibody levels to Staphylococcus aureus exotoxins are associated with sepsis in hospitalized adults with invasive S. aureus infections. J Infect Dis (2012) 206:915-23. doi:10.1093/infdis/jis462

167. Fournier B, Philpott DJ. Recognition of Staphylococcus aureus by the innate immune system. Clin Microbiol Rev (2005) 18:521-40. doi:10.1128/CMR.18.3. 521-540.2005

168. Krishna S, Miller LS. Host-pathogen interactions between the skin and Staphylococcus aureus. Curr Opin Microbiol (2012) 15:28-35. doi:10.1016/j.mib.2011. 11.003

169. Peres AG, Madrenas J. The broad landscape of immune interactions with Staphylococcus aureus: from commensalism to lethal infections. Burns (2013) 39:380-8. doi:10.1016/j.burns.2012.12.008

170. Kurtz J. Specific memory within innate immune systems. Trends Immunol (2005) 26:186-92. doi:10.1016/j.it.2005.02.001

171. Gjertsson I, Hultgren OH, Stenson M, Holmdahl R, Tarkowski A. Are B lymphocytes of importance in severe Staphylococcus aureus infections? Infect Immun (2000) 68:2431-4. doi:10.1128/IAI.68.5.2431-2434.2000

172. Laupland KB, Church DL, Mucenski M, Sutherland LR, Davies HD. Population-based study of the epidemiology of and the risk factors for invasive Staphylococcus aureus infections. J Infect Dis (2003) 187:1452-9. doi:10.1086/374621

173. Spellberg B, Ibrahim AS, Yeaman MR, Lin L, Fu Y, Avanesian V, et al. The antifungal vaccine derived from the recombinant $\mathrm{N}$ terminus of Als3p protects mice against the bacterium Staphylococcus aureus. Infect Immun (2008) 76:4574-80. doi:10.1128/IAI.00700-08

174. Goodyear CS, Silverman GJ. Death by a B cell superantigen: in vivo VH-targeted apoptotic supraclonal B cell deletion by a Staphylococcal Toxin. J Exp Med (2003) 197:1125-39. doi:10.1084/jem.20020552
175. Falugi F, Kim HK, Missiakas DM, Schneewind O. Role of protein A in the evasion of host adaptive immune responses by Staphylococcus aureus. MBio (2013) 4(5):e575-513. doi:10.1128/mBio.00575-13

176. Kobayashi SD, Deleo FR. Staphylococcus aureus protein A promotes immune suppression. MBio (2013) 4(5):e764-713. doi:10.1128/mBio.00764- 13

177. Dryla A, Prustomersky S, Gelbmann D, Hanner M, Bettinger E, Kocsis B, et al. Comparison of antibody repertoires against Staphylococcus aureus in healthy individuals and in acutely infected patients. Clin Diagn Lab Immunol (2005) 12(3):387-98.

178. Verkaik NJ, de Vogel CP, Boelens HA, Grumann D, Hoogenboezem T, Vink C, et al. Anti-staphylococcal humoral immune response in persistent nasal carriers and noncarriers of Staphylococcus aureus. J Infect Dis (2009) 199:625-32. doi:10.1086/596743

179. Harrison LM, Morris JA, Lauder RM, Telford DR. Staphylococcal pyrogenic toxins in infant urine samples: a possible marker of transient bacteraemia. J Clin Pathol (2009) 62:735-8. doi:10.1136/jcp.2008.057232

180. Holtfreter S, Nguyen TT, Wertheim H, Steil L, Kusch H, Truong QP, et al. Human immune proteome in experimental colonization with Staphylococcus aureus. Clin Vaccine Immunol (2009) 16:1607-14. doi:10.1128/CVI.00263-09

181. Burian M, Grumann D, Holtfreter S, Wolz C, Goerke C, Broker BM. Expression of staphylococcal superantigens during nasal colonization is not sufficient to induce a systemic neutralizing antibody response in humans. Eur J Clin Microbiol Infect Dis (2012) 31:251-6. doi:10.1007/s10096-011-1302-2

182. Verkaik NJ, Lebon A, de Vogel CP, Hooijkaas H, Verbrugh HA, Jaddoe VW, et al. Induction of antibodies by Staphylococcus aureus nasal colonization in young children. Clin Microbiol Infect (2010) 16:1312-7. doi:10.1111/j.14690691.2009.03073.x

183. Prevaes SM, van Wamel WJ, de Vogel CP, Veenhoven RH, van Gils EJ, van Belkum A, et al. Nasopharyngeal colonization elicits antibody responses to staphylococcal and pneumococcal proteins that are not associated with a reduced risk of subsequent carriage. Infect Immun (2012) 80:2186-93. doi:10.1128/IAI.00037-12

184. Colque-Navarro P, Jacobsson G, Andersson R, Flock JI, Mollby R. Levels of antibody against 11 Staphylococcus aureus antigens in a healthy population. Clin Vaccine Immunol (2010) 17:1117-23. doi:10.1128/CVI.00506-09

185. Schaffer AC, Solinga RM, Cocchiaro J, Portoles M, Kiser KB, Risley A, et al. Immunization with Staphylococcus aureus clumping factor B, a major determinant in nasal carriage, reduces nasal colonization in a murine model. Infect Immun (2006) 74:2145-53. doi:10.1128/IAI.74.4.2145-2153.2006

186. Verkaik NJ, Boelens HA, de Vogel CP, Tavakol M, Bode LG, Verbrugh HA, et al. Heterogeneity of the humoral immune response following Staphylococcus aureus bacteremia. Eur J Clin Microbiol Infect Dis (2010) 29:509-18. doi:10.1007/s10096-010-0888-0

187. Johansson MA, Saghafian-Hedengren S, Haileselassie Y, Roos S, TroyeBlomberg M, Nilsson C, et al. Early-life gut bacteria associate with IL-4-, IL-10and IFN-gamma production at two years of age. PLoS One (2012) 7:e49315. doi:10.1371/journal.pone.0049315

188. Bjorksten B, Sepp E, Julge K, Voor T, Mikelsaar M. Allergy development and the intestinal microflora during the first year of life. J Allergy Clin Immunol (2001) 108:516-20. doi:10.1067/mai.2001.118130

189. Gisch K, Gehrke N, Bros M, Priesmeyer C, Knop J, Reske-Kunz AB, et al. Formalin-fixed Staphylococcus aureus particles prevent allergic sensitization in a murine model of type I allergy. Int Arch Allergy Immunol (2007) 144:183-96. doi:10.1159/000103991

190. Pastacaldi C, Lewis P, Howarth P. Staphylococci and staphylococcal superantigens in asthma and rhinitis: a systematic review and meta-analysis. Allergy (2011) 66:549-55. doi:10.1111/j.1398-9995.2010.02502.x

191. Kim MR, Hong SW, Choi EB, Lee WH, Kim YS, Jeon SG, et al. Staphylococcus aureus-derived extracellular vesicles induce neutrophilic pulmonary inflammation via both Th1 and Th17 cell responses. Allergy (2012) 67:1271-81. doi:10.1111/all.12001

192. Archer NK, Harro JM, Shirtliff ME. Clearance of Staphylococcus aureus nasal carriage is $\mathrm{T}$ cell dependent and mediated through interleukin-17A expression and neutrophil influx. Infect Immun (2013) 81:2070-5. doi:10.1128/IAI. 00084- 13

193. Machura E, Mazur B, Golemiec E, Pindel M, Halkiewicz F. Staphylococcus aureus skin colonization in atopic dermatitis children is associated with decreased 
IFN-gamma production by peripheral blood CD4+ and CD8+ T cells. Pediatr Allergy Immunol (2008) 19(1):37-45.

194. Quinn GA, Tarwater PM, Cole AM. Subversion of interleukin-1-mediated host defence by a nasal carrier strain of Staphylococcus aureus. Immunology (2009) 128:e222-9. doi:10.1111/j.1365-2567.2008.02952.x

195. Wood AJ, Fraser JD, Swift S, Patterson-Emanuelson EA, Amirapu S, Douglas RG. Intramucosal bacterial microcolonies exist in chronic rhinosinusitis without inducing a local immune response. Am J Rhinol Allergy (2012) 26:265-70. doi:10.2500/ajra.2012.26.3779

196. McLoughlin RM, Lee JC, Kasper DL, Tzianabos AO. IFN-gamma regulated chemokine production determines the outcome of Staphylococcus aureus infection. J Immunol (2008) 181(2):1323-32.

197. McLoughlin RM, Solinga RM, Rich J, Zaleski KJ, Cocchiaro JL, Risley A, et al. CD4+ T cells and CXC chemokines modulate the pathogenesis of Staphylococcus aureus wound infections. Proc Natl Acad Sci U S A (2006) 103:10408-13. doi:10.1073/pnas. 0508961103

198. Mölne L, Corthay A, Holmdahl R, Tarkowski A. Role of gamma/delta T cell receptor-expressing lymphocytes in cutaneous infection caused by Staphylococcus aureus. Clin Exp Immunol (2003) 132(2):209-15.

199. Cho JS, Pietras EM, Garcia NC, Ramos RI, Farzam DM, Monroe HR, et al. IL-17 is essential for host defense against cutaneous Staphylococcus aureus infection in mice. J Clin Invest (2010) 120:1762-73. doi:10.1172/ JCI40891

200. Schmaler M, Jann NJ, Ferracin F, Landmann R. T and B cells are not required for clearing Staphylococcus aureus in systemic infection despite a strong TLR2-MyD88-dependent T cell activation. J Immunol (2011) 186:443-52. doi:10.4049/jimmunol.1001407

201. Ishigame H, Kakuta S, Nagai T, Kadoki M, Nambu A, Komiyama Y, et al. Differential roles of interleukin-17A and -17F in host defense against mucoepithelial bacterial infection and allergic responses. Immunity (2009) 30:108-19. doi:10.1016/j.immuni.2008.11.009

202. Lin L, Ibrahim AS, Xu X, Farber JM, Avanesian V, Baquir B, et al. Th1Th17 cells mediate protective adaptive immunity against Staphylococcus aureus and Candida albicans infection in mice. PLoS Pathog (2009) 5:e1000703. doi:10.1371/journal.ppat.1000703

203. Joshi A, Pancari G, Cope L, Bowman EP, Cua D, Proctor RA, et al. Immunization with Staphylococcus aureus iron regulated surface determinant B (IsdB) confers protection via Th17/IL17 pathway in a murine sepsis model. Hum Vaccin Immunother (2012) 8:336-46. doi:10.4161/hv.18946

204. Ramesh N, Spertini F, Scholl P, Geha R. A toxic shock syndrome toxin-1 peptide that shows homology to mycobacterial heat shock protein 18 is presented as conventional antigen to T cells by multiple HLA-DR alleles. J Immunol (1992) 148:1025-30.

205. Misko IS, Cross SM, Khanna R, Elliott SL, Schmidt C, Pye SJ, et al. Crossreactive recognition of viral, self, and bacterial peptide ligands by human class I-restricted cytotoxic T lymphocyte clonotypes: implications for molecular mimicry in autoimmune disease. Proc Natl Acad Sci U S A (1999) 96:2279-84. doi:10.1073/pnas.96.5.2279

206. Warmerdam PA, Vanderlick K, Vandervoort P, de Smedt H, Plaisance S, de Maeyer M, et al. Staphylokinase-specific cell-mediated immunity in humans. J Immunol (2002) 168(1):155-61.

207. Lawrence PK, Rokbi B, Arnaud-Barbe N, Sutten EL, Norimine J, Lahmers KK, et al. CD4 T cell antigens from Staphylococcus aureus Newman strain identified following immunization with heat-killed bacteria. Clin Vaccine Immunol (2012) 19:477-89. doi:10.1128/CVI.05642-11

208. Kirkpatrick CH. Chronic mucocutaneous candidiasis. Pediatr Infect Dis $J$ (2001) 20:197-206. doi:10.1097/00006454-200102000-00017

209. Puel A, Cypowyj S, Bustamante J, Wright JF, Liu L, Lim HK, et al. Chronic mucocutaneous candidiasis in humans with inborn errors of interleukin-17 immunity. Science (2011) 332:65-8. doi:10.1126/science.1200439

210. Puel A, Cypowyj S, Marodi L, Abel L, Picard C, Casanova JL. Inborn errors of human IL-17 immunity underlie chronic mucocutaneous candidiasis. Curr Opin Allergy Clin Immunol (2012) 12:616-22. doi:10.1097/ACI. ob013e328358cc0b

211. Grimbacher B, Holland SM, Gallin JI, Greenberg F, Hill SC, Malech HL, et al. Hyper-IgE syndrome with recurrent infections - an autosomal dominant multisystem disorder. N Engl J Med (1999) 340:692-702. doi:10.1056/ NEJM199903043400904
212. Freeman AF, Holland SM. Clinical manifestations, etiology, and pathogenesis of the hyper-IgE syndromes. Pediatr Res (2009) 65:32R-7R. doi:10.1203/PDR. 0b013e31819dc8c5

213. Holland SM, Deleo FR, Elloumi HZ, Hsu AP, Uzel G, Brodsky N, et al. STAT3 mutations in the hyper-IgE syndrome. N Engl J Med (2007) 357:1608-19. doi:10.1056/NEJMoa073687

214. Ma CS, Chew GY, Simpson N, Priyadarshi A, Wong M, Grimbacher B, et al. Deficiency of Th17 cells in hyper IgE syndrome due to mutations in STAT3. J Exp Med (2008) 205:1551-7. doi:10.1084/jem.20080218

215. Milner JD, Brenchley JM, Laurence A, Freeman AF, Hill BJ, Elias KM, et al. Impaired $\mathrm{T}(\mathrm{H}) 17$ cell differentiation in subjects with autosomal dominant hyper-IgE syndrome. Nature (2008) 452:773-6. doi:10.1038/nature06764

216. Minegishi Y, Saito M, Nagasawa M, Takada H, Hara T, Tsuchiya S, et al. Molecular explanation for the contradiction between systemic Th17 defect and localized bacterial infection in hyper-IgE syndrome. J Exp Med (2009) 206:1291-301. doi:10.1084/jem.20082767

217. Milner JD, Sandler NG, Douek DC. Th17 cells, Job's syndrome and HIV: opportunities for bacterial and fungal infections. Curr Opin HIV AIDS (2010) 5:179-83. doi:10.1097/COH.0b013e328335ed3e

218. Prendergast A, Prado JG, Kang YH, Chen F, Riddell LA, Luzzi G, et al. HIV-1 infection is characterized by profound depletion of CD161+ Th17 cells and gradual decline in regulatory T cells. AIDS (2010) 24:491-502. doi:10.1097/QAD.0b013e3283344895

219. Foster TJ. Immune evasion by staphylococci. Nat Rev Microbiol (2005) 3:948-58. doi:10.1038/nrmicro1289

220. Ardura MI, Banchereau R, Mejias A, di Pucchio T, Glaser C, Allantaz F, et al. Enhanced monocyte response and decreased central memory $\mathrm{T}$ cells in children with invasive Staphylococcus aureus infections. PLoS One (2009) 4:e5446. doi:10.1371/journal.pone.0005446

221. Banchereau R, Jordan-Villegas A, Ardura M, Mejias A, Baldwin N, Xu H, et al. Host immune transcriptional profiles reflect the variability in clinical disease manifestations in patients with Staphylococcus aureus infections. PLoS One (2012) 7:e34390. doi:10.1371/journal.pone.0034390

222. Peacock SJ, Moore CE, Justice A, Kantzanou M, Story L, Mackie K, et al. Virulent combinations of adhesin and toxin genes in natural populations of Staphylococcus aureus. Infect Immun (2002) 70:4987-96. doi:10.1128/IAI.70.9.49874996.2002

223. Desachy A, Lina G, Vignon P, Hashemzadeh A, Denis F, Etienne J, et al. Role of superantigenic strains in the prognosis of community-acquired methicillinsusceptible Staphylococcus aureus bacteraemia. Clin Microbiol Infect (2007) 13:1131-3. doi:10.1111/j.1469-0691.2007.01810.x

224. Gravet A, Colin DA, Keller D, Girardot R, Monteil H, Prevost G. Characterization of a novel structural member, LukE-LukD, of the bi-component staphylococcal leucotoxins family. FEBS Lett (1998) 436:202-8. doi:10.1016/S00145793(98)01130-2

225. Morinaga N, Kaihou Y, Noda M. Purification, cloning and characterization of variant LukE-LukD with strong leukocidal activity of staphylococcal bi-component leukotoxin family. Microbiol Immunol (2003) 47:81-90. doi:10.1111/j.1348-0421.2003.tb02789.x

226. Lussow AR, MacDonald HR. Differential effects of superantigen-induced "anergy" on priming and effector stages of a $\mathrm{T}$ cell-dependent antibody response. Eur J Immunol (1994) 24:445-9. doi:10.1002/eji.1830240227

227. O'Donnell S, Humphreys H, Hughes D. Distribution of virulence genes among colonising and invasive isolates of methicillin-resistant Staphylococcus aureus. Clin Microbiol Infect (2008) 14:625-6. doi:10.1111/j.1469-0691.2008.01990.x

228. Lee LY, Miyamoto YJ, McIntyre BW, Hook M, McCrea KW, McDevitt D, et al. The Staphylococcus aureus Map protein is an immunomodulator that interferes with T cell-mediated responses. J Clin Invest (2002) 110:1461-71. doi:10.1172/JCI16318

229. Alonzo F III, Kozhaya L, Rawlings SA, Reyes-Robles T, Dumont AL, Myszka DG, et al. CCR5 is a receptor for Staphylococcus aureus leukotoxin ED. Nature (2013) 493:51-5. doi:10.1038/naturel1724

230. Frodermann V, Chau TA, Sayedyahossein S, Toth JM, Heinrichs DE, Madrenas J. A modulatory interleukin-10 response to staphylococcal peptidoglycan prevents Th1/Th17 adaptive immunity to Staphylococcus aureus. JInfect Dis (2011) 204:253-62. doi:10.1093/infdis/jir276

231. Zielinski CE, Mele F, Aschenbrenner D, Jarrossay D, Ronchi F, Gattorno M, et al. Pathogen-induced human TH17 cells produce IFN-gamma or IL-10 
and are regulated by IL-1beta. Nature (2012) 484:514-8. doi:10.1038/ nature 10957

232. Chau TA, McCully ML, Brintnell W, An G, Kasper KJ, Vines ED, et al. Toll-like receptor 2 ligands on the staphylococcal cell wall downregulate superantigeninduced T cell activation and prevent toxic shock syndrome. Nat Med (2009) 15:641-8. doi:10.1038/nm.1965

233. Miller C, Ragheb JA, Schwartz RH. Anergy and cytokine-mediated suppression as distinct superantigen-induced tolerance mechanisms in vivo. J Exp Med (1999) 190:53-64. doi:10.1084/jem.190.1.53

234. Noel C, Florquin S, Goldman M, Braun MY. Chronic exposure to superantigen induces regulatory CD4(+) T cells with IL-10-mediated suppressive activity. Int Immunol (2001) 13:431-9. doi:10.1093/intimm/13.4.431

235. Ziegler C, Goldmann O, Hobeika E, Geffers R, Peters G, Medina E. The dynamics of T cells during persistent Staphylococcus aureus infection: from antigenreactivity to in vivo anergy. EMBO Mol Med (2011) 3:652-66. doi:10.1002/ emmm.201100173

236. Parcina M, Miranda-Garcia MA, Durlanik S, Ziegler S, Over B, Georg P, et al. Pathogen-triggered activation of plasmacytoid dendritic cells induces IL-10producing B cells in response to Staphylococcus aureus. J Immunol (2013) 190:1591-602. doi:10.4049/jimmunol.1201222

237. Murphey ED, Fang G, Sherwood ER. Pretreatment with the Gram-positive bacterial cell wall molecule peptidoglycan improves bacterial clearance and decreases inflammation and mortality in mice challenged with Staphylococcus aureus. Crit Care Med (2008) 36:3067-73. doi:10.1097/CCM. 0b013e31818c6fb7

238. Taylor AL, Llewelyn MJ. Superantigen-induced proliferation of human $\mathrm{CD} 4+\mathrm{CD} 25-\mathrm{T}$ cells is followed by a switch to a functional regulatory phenotype. J Immunol (2010) 185:6591-8. doi:10.4049/jimmunol.1002416

239. Rose WE, Eickhoff JC, Shukla SK, Pantrangi M, Rooijakkers S, Cosgrove SE, et al. Elevated serum interleukin-10 at time of hospital admission is predictive of mortality in patients with Staphylococcus aureus bacteremia. J Infect Dis (2012) 206:1604-11. doi:10.1093/infdis/jis552

240. Lee BY, Ufberg PJ, Bailey RR, Wiringa AE, Smith KJ, Nowalk AJ, et al. The potential economic value of a Staphylococcus aureus vaccine for neonates. Vaccine (2010) 28:4653-60. doi:10.1016/j.vaccine.2010.05.062

241. Lee BY, Wiringa AE, Bailey RR, Lewis GJ, Feura J, Muder RR. Staphylococcus aureus vaccine for orthopedic patients: an economic model and analysis. Vaccine (2010) 28:2465-71. doi:10.1016/j.vaccine.2009.12.075

242. Song Y, Tai JH, Bartsch SM, Zimmerman RK, Muder RR, Lee BY. The potential economic value of a Staphylococcus aureus vaccine among hemodialysis patients. Vaccine (2012) 30:3675-82. doi:10.1016/j.vaccine.2012.03.031

243. Shinefield H, Black S, Fattom A, Horwith G, Rasgon S, Ordonez J, et al. Use of a Staphylococcus aureus conjugate vaccine in patients receiving hemodialysis. N Engl J Med (2002) 346:491-6. doi:10.1056/NEJMoa011297

244. Capparelli EV, Bloom BT, Kueser TJ, Oelberg DG, Bifano EM, White RD, et al. Multicenter study to determine antibody concentrations and assess the safety of administration of INH-A21, a donor-selected human Staphylococcal immune globulin, in low-birth-weight infants. Antimicrob Agents Chemother (2005) 49:4121-7. doi:10.1128/AAC.49.10.4121-4127.2005

245. Shinefield HR. Use of a conjugate polysaccharide vaccine in the prevention of invasive staphylococcal disease: is an additional vaccine needed or possible? Vaccine (2006) 24(Suppl 2):S65-9. doi:10.1016/j.vaccine.2005.01.126

246. Weems JJ Jr, Steinberg JP, Filler S, Baddley JW, Corey GR, Sampathkumar $\mathrm{P}$, et al. Phase II, randomized, double-blind, multicenter study comparing the safety and pharmacokinetics of tefibazumab to placebo for treatment of Staphylococcus aureus bacteremia. Antimicrob Agents Chemother (2006) 50:2751-5. doi:10.1128/AAC.00096-06

247. DeJonge M, Burchfield D, Bloom B, Duenas M, Walker W, Polak M, et al. Clinical trial of safety and efficacy of INH-A21 for the prevention of nosocomial staphylococcal bloodstream infection in premature infants. J Pediatr (2007) 151(260-265):265e261. doi:10.1016/j.jpeds.2007.04.060

248. Weisman LE, Thackray HM, Steinhorn RH, Walsh WF, Lassiter HA, Dhanireddy $\mathrm{R}$, et al. A randomized study of a monoclonal antibody (pagibaximab) to prevent staphylococcal sepsis. Pediatrics (2011) 128:271-9. doi:10.1542/peds. 2010-3081

249. Fowler VG, Allen KB, Moreira ED, Moustafa M, Isgro F, Boucher HW, et al. Effect of an investigational vaccine for preventing staphylococcus aureus infections after cardiothoracic surgery: a randomized trial. JAMA (2013) 309:1368-78. doi:10.1001/jama.2013.3010
250. Creech CB II, Johnson BG, Alsentzer AR, Hohenboken M, Edwards KM, Talbot TR III. Vaccination as infection control: a pilot study to determine the impact of Staphylococcus aureus vaccination on nasal carriage. Vaccine (2009) 28:256-60. doi:10.1016/j.vaccine.2009.09.088

251. Kuklin NA, Clark DJ, Secore S, Cook J, Cope LD, McNeely T, et al. A novel Staphylococcus aureus vaccine: iron surface determinant B induces rapid antibody responses in rhesus macaques and specific increased survival in a murine S. aureus sepsis model. Infect Immun (2006) 74:2215-23. doi:10.1128/IAI.74. 4.2215-2223.2006

252. Zorman JK, Esser M, Raedler M, Kreiswirth BN, Ala'Aldeen DA, Kartsonis N, et al. Naturally occurring IgG antibody levels to the Staphylococcus aureus protein IsdB in humans. Hum Vaccin Immunother (2013) 9(9):1857-64. doi:10.4161/hv.25253

253. Moustafa M, Aronoff GR, Chandran C, Hartzel JS, Smugar SS, Galphin CM, et al. Phase IIa study of the immunogenicity and safety of the novel Staphylococcus aureus vaccine V710 in adults with end-stage renal disease receiving hemodialysis. Clin Vaccine Immunol (2012) 19:1509-16. doi:10.1128/CVI. 00034- 12

254. MacGregor RR. Corynebacterium diphtheriae. In: Mandell, Douglas and Bennett's Principles and Practices of Infectious Diseases. Philadelphia: Elsevier (2010).

255. Murphy TF. Haemophilus species (including H. influenzae and Chancroid). In: Mandell, Douglas and Bennett's Principles and Practices of Infectious Diseases. Philadelphia: Elsevier (2010).

256. Davis SM, Deloria-Knoll M, Kassa HT, O'Brien KL. Impact of pneumococcal conjugate vaccines on nasopharyngeal carriage and invasive disease among unvaccinated people: review of evidence on indirect effects. Vaccine (2013) 32(1):133-45. doi:10.1016/j.vaccine.2013.05.005

257. Garzoni C, Kelley WL. Staphylococcus aureus: new evidence for intracellular persistence. Trends Microbiol (2009) 17:59-65. doi:10.1016/j.tim.2008.11.005

258. Cypowyj S, Picard C, Maródi L, Casanova J-L, Puel A. Immunity to infection in IL-17-deficient mice and humans. Eur J Immunol (2012) 42:2246-54. doi:10.1002/eji.201242605

259. Fallon PG. Immunopathology of schistosomiasis: a cautionary tale of mice and men. Immunol Today (2000) 21:29-35. doi:10.1016/S0167-5699(99)01551-0

260. Therrien R, Lacasse P, Grondin G, Talbot BG. Lack of protection of mice against Staphylococcus aureus despite a significant immune response to immunization with a DNA vaccine encoding collagen-binding protein. Vaccine (2007) 25:5053-61. doi:10.1016/j.vaccine.2007.04.067

261. Prince GA, Jenson AB, Horswood RL, Camargo E, Chanock RM. The pathogenesis of respiratory syncytial virus infection in cotton rats. Am J Pathol (1978) 93:771-91.

262. Kokai-Kun JF. The cotton rat as a model for Staphylococcus aureus nasal colonization in humans: cotton rat S. aureus nasal colonization model. Methods Mol Biol (2008) 431:241-54.

263. Beeson PB, Brannon ES, Warren JV. Observations on the sites of removal of bacteria from the blood in patients with bacterial endocarditis. J Exp Med (1945) 81:9-23. doi:10.1084/jem.81.1.9

264. Haimi-Cohen Y, Vellozzi EM, Rubin LG. Initial concentration of Staphylococcus epidermidis in simulated pediatric blood cultures correlates with time to positive results with the automated, continuously monitored BACTEC blood culture system. J Clin Microbiol (2002) 40:898-901. doi:10.1128/JCM.40.3.898901.2002

265. Khatib R, Riederer K, Saeed S, Johnson LB, Fakih MG, Sharma M, et al. Time to positivity in Staphylococcus aureus bacteremia: possible correlation with the source and outcome of infection. Clin Infect Dis (2005) 41:594-8. doi: $10.1086 / 432472$

266. Corey GR. Staphylococcus aureus bloodstream infections: definitions and treatment. Clin Infect Dis (2009) 48(Suppl 4):S254-9. doi:10.1086/598186

Conflict of Interest Statement: The authors declare that the research was conducted in the absence of any commercial or financial relationships that could be construed as a potential conflict of interest.

Received: 30 October 2013; accepted: 21 December 2013; published online: 08 January 2014.

Citation: Brown AF, Leech JM, Rogers TR and McLoughlin RM (2014) Staphylococcus aureus colonization: modulation of host immune response and impact on human vaccine design. Front. Immunol. 4:507. doi: 10.3389/fimmu.2013.00507 
This article was submitted to Microbial Immunology, a section of the journal Frontiers in Immunology.

Copyright ( () 2014 Brown, Leech, Rogers and McLoughlin. This is an open-access article distributed under the terms of the Creative Commons Attribution License (CC
BY). The use, distribution or reproduction in other forums is permitted, provided the original author(s) or licensor are credited and that the original publication in this journal is cited, in accordance with accepted academic practice. No use, distribution or reproduction is permitted which does not comply with these terms. 